\title{
Predesign cost estimation of a potential wastewater treatment plant for Jordan petroleum refinery- Electrocoagulation
}

Simon Sakhel ( $\sim$ simonsakhel@hotmail.com )

Technische Universitat Berlin

Sven-Uwe Geissen

Technische Universitat Berlin

\section{Research Article}

Keywords: fixed capital investment, working capital, total capital investment, electrocoagulation (EC), annual operating cost, MENA

Posted Date: December 14th, 2021

DOI: https://doi.org/10.21203/rs.3.rs-1073832/v1

License: (c) (i) This work is licensed under a Creative Commons Attribution 4.0 International License.

Read Full License

Version of Record: A version of this preprint was published at Environmental Processes on January 24th, 2022. See the published version at https://doi.org/10.1007/s40710-022-00560-4. 
1 Predesign cost estimation of a potential wastewater treatment plant for Jordan

2 petroleum refinery-Electrocoagulation

4 Simon R. Sakhel

5 Technische Universitaet Berlin

$6 \quad$ Institut fuer Technischen Umweltschutz

$7 \quad$ FG Umweltverfahrenstechnik

$8 \quad$ Strasse des 17 Juni 135

9 D-10623 Berlin

10 Germany

11 e-mail: simonsakhel@hotmail.com (to whom correspondence should be addressed)

12

13 Sven-Uwe Geissen

14 Technische Universitaet Berlin

15 Institut fuer Technischen Umweltschutz

16 FG Umweltverfahrenstechnik

17 Strasse des 17 Juni 135

18 D-10623 Berlin

19 Germany

20 e-mail: sven.geissen@tu-berlin.de

21 Abstract The aim of this paper is to investigate whether simulated Jordan refinery wastewater can be

22 treated through electrocoagulation $(\mathrm{EC})$ to conform to the most stringent Jordanian norms for reusing

23 this wastewater for irrigation of cut flowers and to perform cost analysis for a treatment plant whose

24 core are the EC reactors. The method used for estimating the fixed (capital) costs of the treatment plant

25 is taken from literature and is based on a study estimate (factored estimate) that depends on the

26 knowledge of major items of equipment. Most of the operating costs are estimated based on 
27 percentages which are also taken from literature. The best percentage removal of COD, BOD, TSS, fat,

28 oil\& grease (FOG), bicarbonate $\left(\mathrm{HCO}_{3}{ }^{-}\right)$, and phenol from simulated Jordan refinery wastewater so that

29 it conforms to Jordanian norms were $84.4 \%, 82.1 \%, 27.3 \%$, at least $98.8 \%, 94.9 \%$, at least $96.7 \%$,

30 respectively, at a current of $10 \mathrm{~A}$, treatment time of 5 minutes, $\mathrm{Al} / \mathrm{SS}$ electrodes, and inter-electrode

31 distance $10 \mathrm{~mm}$. Overall treatment costs for the simulated wastewater was $10.75 \$ / \mathrm{m}^{3}(27 \$ / \mathrm{kg}$

$\left.32 \mathrm{COD}_{\text {removed }}\right)$. It is concluded that simulated Jordan refinery wastewater cannot be treated so that it

33 conforms to the most stringent norms for using the treated wastewater for cut flowers irrigation but

34 could be treated enough to conform to the Jordanian norms for using the treated water for irrigation of

35 cooked vegetables, parks, and playgrounds. Moreover, EC is a suitable technology for the treatment of

36 Jordanian recalcitrant refinery wastewater and the cost for its treatment is affordable.

37

38 Keywords: fixed capital investment; working capital; total capital investment; electrocoagulation (EC);

39 annual operating cost; MENA.

40 Highlights

- Electrocoagulation of Jordan refinery wastewater has been performed

- Removal of at least $96.7 \%$ phenol, at least $98.8 \%$ Fat, oil, and grease (FOG), $27.3 \%$ TSS, $84.4 \%$ $\mathrm{COD}, 82.1 \% \mathrm{BOD}_{5}$, and $94.9 \%$ bicarbonate in Jordan petroleum refinery wastewater.

- Best result: $10 \mathrm{~A}$ current intensity, 5 minutes electrocoagulation (reaction) time.

- Cost analysis of a treatment plant for Jordan petroleum refinery whose core is Electrocoagulation

\section{Introduction}

A large part of the wastewater in the Middle East and North Africa (MENA) conveyed in sewerage receives minimal or no treatment and is finally discharged either on land, sea, or surface water. It is also 
50 likely that a larger fraction of wastewater from septic tanks is discharged outside conventional

51 treatment systems thereby not receiving any treatment at all (Jeuland 2015). The focus in MENA has

52 been on the collection and treatment of domestic wastewater mixed with industrial effluents (if

53 present) and presumably little or no attention is being paid to appropriate treatment of industrial

54 wastewater before its discharge to the environment (For example, Jordan's petroleum refinery

55 mechanically treated wastewater is used for irrigation) or to the sewer network. Industrial wastewater

56 treatment helps in keeping good-quality water resources for high-value uses, such as potable water,

57 environmental protection through reducing pollution which causes the control of environmental

58 degradation, and reducing water withdrawal either from the surface or ground (Jeuland 2015). There

59 are not any statistics available on the volume of industrial wastewater generated in MENA, however, it

60 is known that for domestic and industrial effluents it is $13.24 \mathrm{~km}^{3} / \mathrm{yr}$ (Qadir et al. 2010). $43.1 \%$ of the

61 latter is treated and about $83 \%$ of the treated wastewater volume is used for irrigation (Qadir et al.

62 2010). Presumably, a major part of the industries in MENA do not treat their industrial wastewater. For

63 example in Jordan's Amman-Zarqa region there are industries which discharge their effluents untreated

64 to the municipal sewer or to the environment leading to pollution (Mohsen and Jaber 2002).

65 Another polluting industry in MENA is petroleum refining which is considered a major industry in

66 this region as its share of the Gross Domestic Product (GDP) is between 0.2 to $4.2 \%$ (Sakhel et al. 2017).

67 It is estimated that the annual wastewater volume from this industry is about 217.5 million $\mathrm{m}^{3}$ (Sakhel et

68 al. 2017) and these effluents are a major source for aquatic pollution (Wake 2005). They contain oil and

69 grease and many other toxic compounds such as benzene, toluene, ethylbenzene, and xylene which are

70 considered to be the most hazardous compounds released into the environment (Diya'uddeen et al.

71 2011, Saber et al. 2014). Moreover, refinery wastewater usually contains recalcitrant organic material

72 such as polyaromatic hydrocarbons and phenols that are barely degradable by nature (Al-Khalid and El-

73 Naas 2018). Traditional treatment of petroleum refinery wastewater (PRW) which is based on 
74 mechanical and physicochemical methods leads to incomplete removal of refractory compounds

75 (Panizza 2018). Discharging recalcitrant compounds to the environment can lead to their accumulation

76 in human and animal tissues after long distance transport. Therefore, an appropriate treatment method

77 for removal of these compounds is necessary.

78 EC has emerged as a promising technique for PRW treatment. It has not only the ability of removing 79 particulate COD (García-Morales et al. 2018) but it also removes soluble COD from wastewater 80 containing petroleum hydrocarbons (Asselin et al. 2008). Having the ability of removing both is a 81 privilege and is the primary purpose of wastewater treatment (Jimenez et al. 2005). Moreover, 82 recalcitrant organic material, usually present in refinery effluents, can be removed or eliminated using 83 EC (Fayad 2017, Pérez et al. 2015). For example, this technique has been successfully applied for the 84 removal of phenol, one of the recalcitrant compounds present in refinery wastewater (Gasim et al. 85 2012), through the use of EC (Abdelwahab et al. 2009, El-Ashtoukhy et al. 2013). The capability of EC in 86 removing soluble recalcitrant compounds (e.g. phenols) infers that this technique may be able to

87 remove other similar substances all which are reflected in the lumped recalcitrant COD parameter. 88 Keramati and Ayati (2019) found out that treating PRW through EC leads to the removal of non89 degradable compounds from this effluent. Moreover, Pérez et al. (2015) treated PRW with a BOD/COD ratio less than $0.3(0.015)$ through EC. This treatment technology increased the BOD/COD ratio up to 0.5

91 which indicates that this technique was able to remove recalcitrant and/or toxic substances in the 92 refinery effluent (Al-Qodah et al. 2019). The study of Pérez et al. (2015) reflects that EC can remove 93 recalcitrant COD. Recalcitrant COD removal is usually associated with high removal costs (Wang et al. 94 2011) since refractory compounds cannot be eliminated through conventional biological treatment 95 processes which are considered economical (e.g. activated sludge process) (Li 2013; Choi et al. 2017) but 96 require processes that can deal with these refractory compounds (e.g. EC, Advanced Oxidation 97 Processes (AOPs), membranes) (Kulikowska et al. 2019; Sristav et al. 2019; Pérez et al. 2015). 
There have been efforts that estimated the operating costs for the removal of COD from PRW as well as other types of wastewater using EC (Giwa et al. 2013; Keramati and Ayati 2019; Aygun et al. 2019; Asselin et al. 2008; Demirci et al. 2015; Said and Mostefa 2015; Elazzouzi et al. 2017; Kobya et al. 2009; Mahesh et al. 2016; Yuksel et al. 2012; Varank et al. 2014; Mohammadi et al. 2017; Deghles and Kurt 2015; Guvenc et al. 2017; Chopra and Sharma 2015; Kongjao et al. 2008; Akyol 2012; Chauhan et al. 2016; Sridhar et al. 2014; Sahu et al. 2015; Bassala et al. 2017; Kobya and Delipinar 2008). For example, Giwa et al. (2013) and Keramati and Ayati (2019) estimated the operating costs at optimum experimental conditions for treating PRW through EC to be 0.654 US $\$ / \mathrm{m}^{3}$ (6.4 US $\$ / \mathrm{kg} \mathrm{COD}_{\text {removed }}$ ) and 1.45 US $\$ / \mathrm{m}^{3}$ (1.7 US $\$ / \mathrm{kg} \mathrm{COD}_{\text {removed }}$ ), respectively. Aygun et al. (2019) estimated the operating costs at optimal conditions for treating textile industry wastewater through EC using Al and Fe electrodes in monopolar configuration to be $1.84 € / \mathrm{m}^{3}$ (5.8 $€ / \mathrm{kg}$ COD $\left._{\text {removed }}\right)$ and $1.56 € / \mathrm{m}^{3}$ (4.6 $€ / \mathrm{kg}$ COD $_{\text {removed }}$ ), respectively. Asselin et al. (2008) estimated the operating costs (energy, chemicals, electrode consumption, and sludge disposal costs) at optimal conditions for treating oily bilgewater (OBW) using EC to be 0.46 US $\$ / \mathrm{m}^{3}$ (0.8 US $\$ / \mathrm{kg} \mathrm{COD}_{\text {removed }}$ ). Demirci et al. (2015) estimated the operating costs (consists of energy, and electrode consumption) for the treatment of textile industry wastewater through EC using Al and Fe electrodes to be $6.439 € / \mathrm{m}^{3}\left(1.6 € / \mathrm{kg} \operatorname{COD}_{\text {removed }}\right)$ and $4.732 € / \mathrm{m}^{3}(1.3 € / \mathrm{kg}$ $\mathrm{COD}_{\text {removed }}$ ), respectively. Chauhan et al. (2016) estimated the operating costs (electrical energy and electrode costs) for the treatment of 4-chlorophenol (CP) through electrochemical oxidation by using a dimensionally stable anode (DSA) namely ruthenium oxide coated titanium (Ti/RuO2) to be 189.1 US $\$ / \mathrm{m} 3$ (1062.8 US $\$ / \mathrm{kg}$ COD $_{\text {removed }}$ ). Sridhar et al. (2014) estimated the operating cost (energy, chemicals, and electrode consumption) for the treatment of egg processing effluent through electrocoagulation using aluminium electrodes under optimal conditions to be 2.7 US $\$ / \mathrm{m} 3\left(0.81 \mathrm{US} \$ / \mathrm{kg} \mathrm{COD}_{\text {removed }}\right)$. Sahu et al. (2015) estimated the operating costs (electrical energy and electrode costs) for the treatment of actual sugar industry wastewater through electrocoagulation using aluminium electrodes under optimal 
122 conditions to be 6.22 US $\$ / \mathrm{m} 3$ (2.14 US $\$ / \mathrm{kg}$ COD $_{\text {removed }}$ ). Bassala et al. (2017) estimated the operating 123 costs (energy and electrode costs) for the treatment of dairy industry wastewater through 124 electrocoagulation using aluminium electrodes to be 0.026 US $\$ / \mathrm{m} 3$ (0.042 US $\left.\$ / \mathrm{kg} \mathrm{COD}_{\text {removed }}\right)$. Kobya 125 and Delipinar (2008) estimated the operating cost (energy, chemicals, and electrode consumption) for 126 the treatment of baker's yeast wastewater through electrocoagulation using aluminium and iron 127 electrodes under optimal conditions to be 1.54 US $\$ / \mathrm{m}^{3}$ (0.82 US $\$ / \mathrm{kg}$ COD removed) and 0.51 US $\$ / \mathrm{m}^{3}$ 128 (0.27 US $\$ / \mathrm{kg} \mathrm{COD}_{\text {removed }}$ ), respectively. Finally, Chopra and Sharma (2015) estimated the operating costs 129 (consists of energy, and electrode consumption) for the treatment of secondarily treated sewage 130 (recalcitrant wastewater) through EC using Al electrodes at optimum conditions to be 1.56 US $\$ / \mathrm{m}^{3}$ 131 (17.8 US $\$ / \mathrm{kg}$ recalcitrant $\mathrm{COD}_{\text {removed }}$ ). Additionally, there are only some studies present that discuss the 132 overall cost (fixed and operating) whether at bench or pilot scale for the treatment of domestic 133 wastewater using electrocoagulation (Lin et al. 2005), textile dye wastewater using chemical oxidation 134 and biological treatment (El-Dein et al. 2006), real wastewater from olive oil mills and fine-chemical 135 manufacturing plants using AOPs (Cañizares et al. 2009), soluble oil wastes with high COD using 136 electrocoagulation (Calvo et al. 2003), and domestic wastewater using electrocoagulation, electro137 fenton and electro-oxidation (Gaied et al. 2019). The few aforementioned studies (Lin et al. 2005, El138 Dein et al. 2006, Cañizares et al. 2009, Calvo et al. 2003, and Gaied et al. 2019) did capital and operating 139 costs for plants that have a capacity ranging from 1 to $28 \mathrm{~m}^{3} /$ day and none did the cost analysis on 140 treating petroleum refinery wastewater at full-scale. Moreover, a few studies are present for costs 141 relevant to treatment of different industrial wastewaters using EC at full-scale. Tetreault (2003) reported 142 a slaughterhouse that used EC technology for the treatment of a mixture of stick/blood water and 143 presented capital/operating costs. Eames et al (2017) reported silica removal in mineral 144 mining/processing and oil/gas extraction wastewaters at full-scale using a treatment train that included 145 EC and presented capital/operating costs. The scarcity of research relevant to overall costs for different 
146 types of wastewater treatment at full-scale led to doing the present research in order to enrich

147 literature in this area especially relevant to an effluent (here petroleum refinery wastewater) that is

148 recalcitrant. Overall costs need to be estimated especially at full-scale since it is a major criterion for

149 industry when choosing the desired treatment technology. According to the best authors knowledge

150 there is no research available that talks about the treatment of JRWW through electrocoagulation. The

151 novelty of this study lies in: 1-Studying the possibility of using EC for treating simulated JRWW using the

152 following combinations of electrodes: Aluminum/stainless steel (anode/cathode) and mild

153 steel/stainless steel (anode/cathode) in a bipolar electrode configuration, to an extent so that it

154 conforms to the most stringent Jordanian norms relevant to COD, BOD, TSS, fat, oil and grease (FOG),

155 phenol, and $\mathrm{HCO} 3$ so that it could be used for irrigation of cut flowers; 2-highlighting practical

156 knowledge and estimation of operating/capital costs in addition to electrical energy consumption for a

157 full-scale wastewater treatment plant $\left(3,840 \mathrm{~m}^{3} /\right.$ day) treating JRWW through EC which is missing in

158 scientific literature. Additionally, it estimates the recalcitrant COD removal costs (fixed and operating)

159 through EC for JRWW that is only mechanically treated. So the research questions the paper tries to

160 answer are: Is EC a suitable technology for the treatment of Jordanian recalcitrant refinery wastewater?

161 Are the costs relevant to the treatment of the aforementioned industrial effluent affordable?

162 The paper is organized as follows: in "Important terms", we define important terms. "Experimental

163 section-Materials and Methods", we describe the experimental set-up, synthetic petroleum refinery

164 wastewater, measurement methods, and sludge characteristics. "Methodology relevant to finding fixed

165 and operating costs of EC treatment plant", we summarize the methodology used for the cost

166 calculations. "Results and interpretations", we present our results. "Discussion", we discuss our results.

167 "Conclusions", we end with conclusions.

1682 Important terms 
170

171

172 Fixed capital investment: is the money needed to purchase and install the necessary machinery and

173 equipment for a plant

174

175 Working capital: is the capital set aside by the investor in the beginning to use it afterwards in case of an

176 emergency (e.g. failure or calamity of plant) in order to keep the plant in operation or bring the plant

177 back to operational requirements

178

179

180

181

182

183

184

185

186

187

188

\subsection{Definition of important terms}

Total capital investment: is the sum of fixed capital investment and working capital

\section{Experimental section-Materials and Methods}

\subsection{Experimental Set-Up}

The treatment of synthetic JRWW was done in a batch reactor made from $6 \mathrm{~mm}$ thick polypropylene sheet material. The EC cell consisted of 8 electrodes that were connected in bipolar configuration. In bipolar configuration trials 4 aluminium/4 stainless steel (SS) plates or 4 mild steel (MS)/4 SS plates were used arranged as AI-AI-AI-AI-SS-SS-SS-SS or MS-MS-MS-MS-SS-SS-SS-SS. The aluminum or the mild steel was connected to the anode while stainless steel was the cathode. A schematic diagram of the EC cell is shown in Fig.1. 


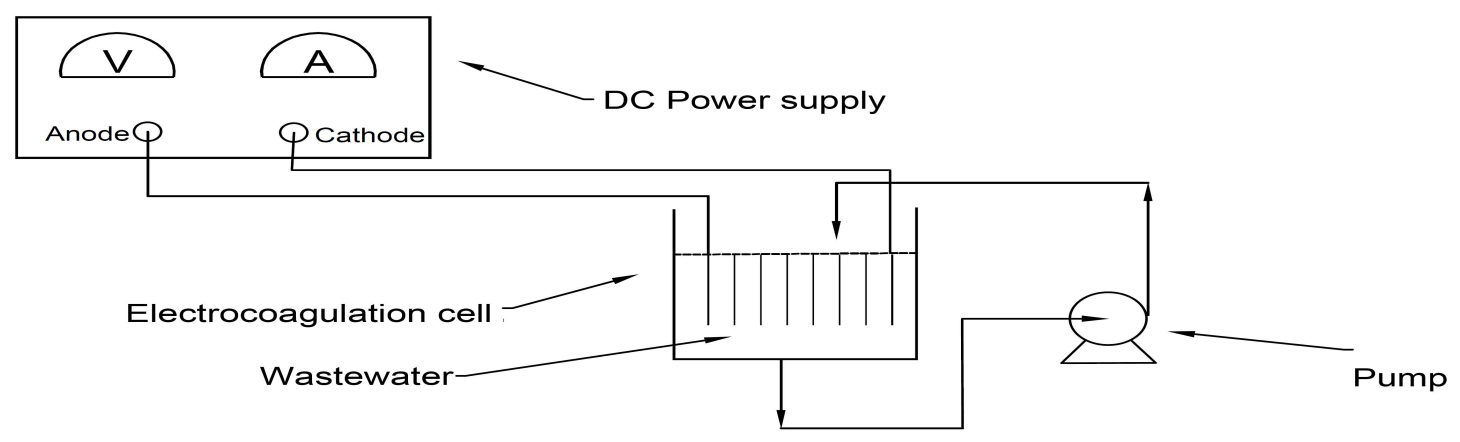

190 Fig. 1 Schematic diagram of the EC cell in a bipolar connection mode

191 The aluminum, stainless steel and mild steel plates have a height, width, and thickness of 181, 103, and

$1924 \mathrm{~mm}$, respectively. The plates were totally immersed in the synthetic refinery wastewater and the

193 distance between each pair of electrodes is $10 \mathrm{~mm}$ in the trials. A reaction batch of 4 liters of

194 wastewater was used for all the trials. Wastewater was mixed through recirculation from a bottom valve

195 in the reactor using a pump (see Fig.1). Before each run electrodes were washed by dilute $\mathrm{HCl}$ acid wash

196 and then final rinse with tap water to remove oxide and passivation layers. Consumption of energy was

197 calculated using the following equation

Energy consumption $\left(\mathrm{kWh} / \mathrm{m}^{3}\right)=\frac{\mathrm{VIt}}{\text { Treated Volume }} \ldots \ldots \ldots \ldots \ldots \ldots \ldots \ldots \ldots \ldots \ldots \ldots \ldots \ldots \ldots$

where $V$ is the cell voltage in volt, $I$ is the current in $A m p(A), t$ is the treatment time in hour and the treated volume is in liter. The pollutant removal efficiency from wastewater by the EC reactor was calculated using the equation below where $C_{o}$ and $C_{F}$ are the initial and final concentration of pollutant, respectively. 
208 Synthetic petroleum refinery wastewater was prepared according to the concentrations of actual 209 Jordanian petroleum refinery wastewater which was used as a reference. The different concentrations 210 of real Jordan refinery wastewater that is only mechanically treated is shown in Table 1 along with the 211 concentrations of the different parameters that are achieved during preparation of synthetic 212 wastewater. To synthesize the wastewater machine oil lubricant was added to form FOG and was 213 entirely emulsified through blending, Sodium Bicarbonate $\left(\mathrm{NaHCO}_{3}\right)$ was used to form $\mathrm{HCO}_{3}{ }^{-}$, phenol $214\left(\mathrm{C}_{6} \mathrm{H}_{5} \mathrm{OH}\right)$ was used to form phenol, $\mathrm{Na}_{2} \mathrm{SO}_{4}$ was used to form total dissolved solids (TDS), sand was used 215 to form total suspended solids (TSS), Potassium Hydrogen Phthalate $\left(\mathrm{C}_{8} \mathrm{H}_{5} \mathrm{KO}_{4}\right)$ was used to form 216 chemical oxygen demand (COD), cow dung was used to form biological oxygen demand $\left(\mathrm{BOD}_{5}\right)$, and $\mathrm{pH}$ 217 was adjusted to the required value using $0.5 \mathrm{~N}$ hydrochloric acid. All chemicals used during testing are of 218 analytical grade.

219 Table 1 Characteristics of actual and synthetic Jordan petroleum refinery wastewater

\begin{tabular}{|c|c|c|}
\hline Parameter & $\begin{array}{c}\text { Actual Jordanian refinery } \\
\text { wastewater }\end{array}$ & Synthetic refinery wastewater $^{\text {b }}$ \\
\hline $\mathrm{HCO}_{3}, \mathrm{ppm}$ & 568 & 715.5 \\
\hline Phenol, ppm & 0.036 & 0.03 \\
\hline TDS, ppm & 5339 & 5210 \\
\hline Fat, Oil, \& Grease (FOG), ppm & Less than 8 & 8.5 \\
\hline TSS, ppm & 32 & 66 \\
\hline $\mathrm{COD}, \mathrm{ppm}$ & 430 & 472 \\
\hline $\mathrm{BOD}_{5}, \mathrm{ppm}$ & 54 & 56 \\
\hline $\mathrm{pH}$ & 8.43 & 9.36 \\
\hline
\end{tabular}

${ }^{\mathrm{a}}$ The Hashemite Kingdom of Jordan Environment Statistics 2014-2015 (2018) ${ }^{\text {bThis work }}$

\subsection{Measurement Methods}

223 Phenol was determined by UV-spectrophotometry through analyzing the color resulting from the

224 reaction of 4-aminoantipyrine with phenol in the presence of potassium ferricyanide. The antipyrine dye

225 resulting from the reaction of 4-aminoantipyrine with phenol in the presence of potassium ferricyanide

226 is extracted from water with chloroform and the absorbance is measured at $460 \mathrm{~nm}$. $\mathrm{HCO}$ was

227 determined by titrating wastewater samples against a standard solution of sulphuric acid of $0.02 \mathrm{~N}$ using 
228 a phenolphthalein indicator and a mixed indicator (a mixture of methyl red and bromocresol green

229 indicators). The mixed indicator is used to determine the total alkalinity while phenolphthalein indicator

230 is used to determine the phenolphthalein alkalinity. TDS and TSS have been determined by gravimetric

231 methods, FOG have been determined by acidifying the synthetic wastewater sample to $\mathrm{pH}$ less than 2

232 and serially extracting it with trichlorotrifluoroethane $(1,1,2$ trichloro-1,2,2 trifluoroethane) three times

233 in a separatory funnel. The trichlorotrifluoroethane is distilled from the extract and the left residue is

234 desiccated and weighed. COD has been determined by the open reflux method, the dissolved oxygen

235 (DO) was determined by titrimetric procedure (iodometric test) and consequently BOD was calculated

236 from determined DOs, $\mathrm{pH}$ was determined using a digital $\mathrm{pH}$ meter (brand-ultratech). Sludge production

237 (metal hydroxide flocs and removed pollutants) has been determined through total suspended solids

238 measurement (gravimetric method).

$240 \quad 3.4$ Sludge characteristics

241 After the synthetic petroleum refinery wastewater was treated by electrocoagulation a specific volume

242 of reacted water was taken, mixed and transferred to a $250 \mathrm{~mL}$ graduated cylinder and was allowed to 243 settle and the volume of compacted sludge was reported a 0, 10, 20, and 30 minutes in the presence 244 and absence of a flocculating agent. SSV30 and SVI have been determined as follows:

246 The sludge was allowed to settle for a period of 30 minutes and the volume of sludge recorded at this 247 time is the SSV30.

249 The SVI has been calculated using the following formula: 
253 The TSS (MLSS) of the treated wastewater was determined gravimetrically and used in the SVI

254 calculation.

4 Methodology relevant to finding fixed and operating costs of EC treatment plant

256 In this section we summarize the method used. Because it involves lengthy details, its full presentation is

257 relegated to the supplementary material. The rudiments are as follows:

258 a) Selection of the major items of equipment:

259

260 1- Selection of the sludge dewatering machine

Capital, operation, and maintenance costs have been performed on the most prominent techniques used in sludge dewatering by using appropriate cost equations taken from Sharma 2010. The decanter centrifuge was selected for dewatering the sludge generated from EC treatment of JRWW since it had the lowest capital, operation, and maintenance costs among all outstanding techniques considered. are:

- EC is most commonly used in the oil and gas industry to remove emulsified oil, total petroleum hydrocarbons, suspended solids, and heavy metals (Martin 2014). It can process all the 
aforementioned multiple contaminants in just the chamber of the EC (GENESIS WATER TECHNOLOGIES 2019).

- It has low maintenance costs because the system is not easily damaged due to not containing moving parts. Moreover, the metal blades within the reactor can be easily cleaned and replaced inexpensively (GENESIS WATER TECHNOLOGIES 2019). underground sludge tank (UST) to keep the slurry/sludge homogenous inside the tanks. Eight centrifugal slurry pumps ( 3 are standby) were also selected to pump the slurry throughout the TP. One centrifugal submersible sludge pump to be submerged in UST has also been selected.

Table 2 below shows the major items of equipment selected for the EC TP.

289

290
Table 2 Major items of equipment selected for the EC TP

\begin{tabular}{|c|c|}
\hline Number & Major equipment name \\
\hline 1 & 3 EC reactors \\
\hline 2 & $3\left(53.3 \mathrm{~m}^{3} / \mathrm{hr}\right.$ ) feeding pumps to EC reactors \\
\hline 3 & 3 tanks (each tank adjacent to an EC reactor) \\
\hline 4 & $3\left(53.3 \mathrm{~m}^{3} / \mathrm{hr}\right)$ slurry pumps (plus 3 standby) \\
\hline 5 & 1 Concrete slurry tank \\
\hline 6 & 1 hydraulic mixing pump for concrete slurry tank \\
\hline 7 & $2\left(80 \mathrm{~m}^{3} / \mathrm{hr}\right)$ slurry pumps \\
\hline 8 & 2 Lamella clarifiers \\
\hline 9 & 1 UST \\
\hline 10 & 1 hydraulic mixing pump for UST \\
\hline 11 & 1 Submersible sludge pump (26.24 $\left.\mathrm{m}^{3} / \mathrm{hr}\right)$ \\
\hline 12 & 1 Polymer station \\
\hline 13 & 1 Decanter centrifuge \\
\hline
\end{tabular}


291

292

293

294

295

296

297

298

299

300

301

302

303

304

305

306

307

308

309

310

311

$312(1985))]$,

313956 is the density of sludge in units of $\mathrm{kg} / \mathrm{m}^{3}$, equation (Von Sperling and Gonçalves 2007):

c) Hydraulic mixing pump capacity and mixing power

where

MP is the mixing power in units of Watt,

b) \% dry solids content of sludge resulting from the treatment of JRWW through EC.

The \% dry solids content of sludge before dewatering has been calculated using the following

Sludge flow $\left(\mathrm{m}^{3} /\right.$ day $)=$ dry solids load $(\mathrm{kg} /$ day $) /($ dry solids $\% / 100) \times$ Sludge density $\left.\left(\mathrm{kg} / \mathrm{m}^{3}\right)\right) \ldots \ldots .4$

The volumetric sludge generation rate have been determined based on sludge settling tests while the sludge/slurry density and the dry solids load have been determined experimentally to be 956 $\mathrm{kg} / \mathrm{m}^{3}$ and $2.9 \mathrm{~kg}$ dry solids $/ \mathrm{m}^{3}$ based on gravimetric methods.

The mixing pump capacity in the concrete slurry tank and UST as well as mixing power in the aforementioned tanks is calculated according to equation 5 and 6, respectively [US EPA (1985)]

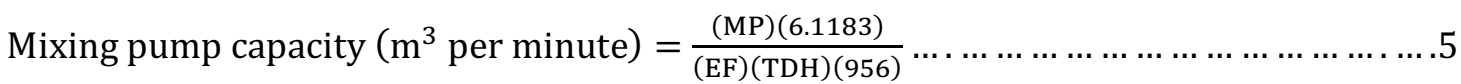

EF is the efficiency of mixing pump of dimensionless units [default value $=0.7$ (US EPA (1985))],

$\mathrm{TDH}$ is the total dynamic head of the pump in units of meter [default value $=7.62 \mathrm{~m}(25 \mathrm{ft}$ ) (US EPA 
3146.1183 is the conversion factor to convert from Watt to $\mathrm{kg}$-meter/min.

315

316

317 where

318

319

320

321

322

323

324

325

326

327

328

329

330

331

332

333

334

335

336

0

1

$\mathrm{MP}($ Watt $)=\mathrm{ME} \times$ Sludge Volume $\times 1.175$

$\ldots \ldots \ldots \ldots \ldots \ldots \ldots \ldots \ldots \ldots$

$\mathrm{ME}$ is the mixing energy in Watt $/ \mathrm{m}^{3}$, and sludge volume is its volume in $\mathrm{m}^{3}$.

d) Decanter centrifuge cake volumetric flow rate estimation

The estimation of this quantity from decanter centrifuge was based on equations 7, 8 and 9 (Records and Sutherland 2001, Celenza 2000)

Mass flow rate of solids to decanter $=$ Mass flow rate of cake solids +

Mass flow rate of centrate solids ... 7 
337 e) Pressure drop (frictional losses) for flow of slurry/sludge in pipes and minor head losses

338

339

340

341

342

343

344

345

346

347

348

349

350

351

352

353

354

355

356

357 In theory, the absolute pressure at the suction port of the pump (NPSHa) should be larger or equal to

358 the minimum pressure required at the suction port of the pump to keep the pump from cavitating

This has been found using equations 10 and 11 below, respectively (McFarland 2000)

$$
\Delta \mathrm{P}=\frac{2 \mathrm{f} \rho \mathrm{LV}}{\mathrm{D}}
$$

$$
\text { Minor head loss }=\mathrm{K}\left(\mathrm{V}^{2} / 2 \mathrm{~g}\right)
$$

where $\Delta \mathrm{P}$ is the pressure drop in pipe in $\mathrm{N} / \mathrm{m}^{2}$, minor head loss in meter, $\mathrm{f}$ is the friction factor found from Fig. 5.3 in McFarland 2000, $\rho$ is the fluid density in $\mathrm{kg} / \mathrm{m}^{3}, \mathrm{~L}$ is the pipe length in $\mathrm{m}, \mathrm{V}$ is the mean velocity of flow in $\mathrm{m} / \mathrm{sec}, \mathrm{D}$ is the pipe diameter in $\mathrm{m}, \mathrm{g}$ is the gravitational acceleration in $\mathrm{m} / \mathrm{s}^{2}$, and $\mathrm{K}$ is the head loss coefficient which is dimensionless.

f) Net positive suction head (NPSH)

The net positive suction head available (NPSHa) has been calculated using equation 12

$$
\text { NPSHa }=\mathrm{Z}+\mathrm{P}_{\mathrm{a}} / \rho \mathrm{g}-\mathrm{P}_{\mathrm{vp}} / \rho \mathrm{g}-\mathrm{h}_{\mathrm{f}}
$$

where NPSHa is in meter, $\mathrm{Z}$ is the difference between the pump impeller eye level and the suction water level in $\mathrm{m}, \mathrm{P}_{\mathrm{a}}$ is the absolute atmospheric pressure in $\mathrm{N} / \mathrm{m}^{2}, \mathrm{P}_{\mathrm{vp}}$ is the absolute vapor pressure of the fluid at pumping temperature in $\mathrm{N} / \mathrm{m}^{2}, \rho$ is the density of fluid in $\mathrm{kg} / \mathrm{m}^{3}, \mathrm{~g}$ is the acceleration of gravity in $\mathrm{m} / \mathrm{s}^{2}$, and $\mathrm{h}_{\mathrm{f}}$ is the head lost in the suction pipework in $\mathrm{m}$. 
359 (NPSHr). However, in practice there should be an additional head added to NPSHr and acts as a buffer

360 against uncertainties of pumping.

361

362 Thus, to avoid pump cavitation $\quad$ NPSHa $\geq$ NPSHr + additional head

363 Where NPSHa, NPSHr and additional head are all in meters.

364

g) Total cost (fixed and operational) estimation:

365

Predesign cost estimation for a potential wastewater TP for Jordan refinery mechanically treated 366 effluent through EC has been performed based on finding the fixed (capital) costs through a study

367 (factored) estimate. The latter requires the knowledge of major items of equipment and the probable 368 accuracy of this estimate is up to $\pm 30 \%$ (Peters and Timmerhaus 1991). The estimated operating costs

369 are the second important part for determining the total costs for treating the wastewater. The total 370 capital investment (fixed capital + working capital) is estimated based on the knowledge of the costs of 371 major items of delivered equipment for a potential EC TP. After knowing the total price of major 372 delivered equipment, the ratio factors for estimating the capital-investment items for a fluid processing 373 plant are then used to find the total capital investment (Peters and Timmerhaus 1991).

h) Power costs

375

The calculation of these costs is mentioned here for three equipments only.

377

1- Power costs for running the pumps

The power costs for running the pumps are calculated using equations 14 and 15 (Giorgi 2009, Neutrium 2012) below 
where $Q$ is the flow rate in $\mathrm{m}^{3} / \mathrm{hr}, \rho$ is the density of fluid in $\mathrm{kg} / \mathrm{m}^{3}, \mathrm{~g}$ is the gravitational acceleration to water efficiency, dimensionless (Theobald 2014).

2- Power costs for running the decanter centrifuge

Annual costs for running decanter centrifuge (US \$/yr)

where decanter centrifuge motor power is in $\mathrm{kW}$, and operating hours per year are in hours.

3- Power costs required for running the EC reactors has been estimated by first calculating the energy consumption in $\mathrm{kWh} / \mathrm{m}^{3}$ using equation 1 and then power costs have been determined as follows

\section{Results and interpretations}

Annual costs for running the 3 EC reactors (US \$/yr) $=$ energy consumption $\left(\mathrm{kWh} / \mathrm{m}^{3}\right) \times$ total wastewater flow rate $\left(\mathrm{m}^{3} / \mathrm{hr}\right)$ $\times 0.154$ US $\$ / \mathrm{kWh} \times 1.175$

\section{$401 \quad$ 5.1.1 Changing electrode material}

402 In EC experiments one of the important factors that determine the efficiency of the process is the type 403 and combinations of electrodes. The type of materials that are used most often for EC experiments are 
404

405

406

407

408

Aluminum (Al) and iron (Stainless Steel (SS)) which are quite cheap (Gousmi et al. 2016). In this work two types of electrode combinations have been used (Anode/Cathode): Al/SS, Mild Steel/SS. The best (optimum) results for removing the synthetic wastewater constituents are shown in Tables 3 and 4.

Table 3 Best results of treatment of synthetic refinery wastewater using Al and SS electrodes at a current of $10 \mathrm{Amp}$, voltage of 28 to 31, inter-electrode distance of $10 \mathrm{~mm}$, and 5 minutes reaction time

\begin{tabular}{|c|c|c|c|c|c|}
\hline Parameter & $\begin{array}{c}\text { Raw synthetic } \\
\text { wastewater }\end{array}$ & $\begin{array}{c}\text { Treated } \\
\text { wastewater }\end{array}$ & $\begin{array}{c}\text { \% removal of } \\
\text { pollutant }\end{array}$ & $\begin{array}{l}\text { Target value } \\
\text { according to } \\
\text { Jordanian } \\
\text { norms for } \\
\text { using the } \\
\text { treated water } \\
\text { for irrigation of } \\
\text { cooked } \\
\text { vegetables, } \\
\text { parks, } \\
\text { playgrounds }\end{array}$ & $\begin{array}{l}\text { Target value } \\
\text { according to } \\
\text { the most } \\
\text { stringent } \\
\text { Jordanian } \\
\text { norms for } \\
\text { using the } \\
\text { treated water } \\
\text { for cut flowers } \\
\text { irrigation }\end{array}$ \\
\hline $\mathrm{HCO}_{3}$ in $\mathrm{ppm}$ & 715.5 & 36.81 & 94.9 & 400 & 400 \\
\hline $\begin{array}{l}\text { Phenol in } \\
\text { ppm }\end{array}$ & 0.03 & $N^{a}$ & At least 96.7 & $\begin{array}{c}\text { Less than } \\
0.002\end{array}$ & $\begin{array}{c}\text { Less than } \\
0.002\end{array}$ \\
\hline TDS in ppm & 5210 & & & & \\
\hline $\begin{array}{l}\text { Fat, oil, and } \\
\text { grease (FOG) } \\
\text { in ppm }\end{array}$ & 8.5 & $N D^{b}$ & At least 98.8 & 8 & 2 \\
\hline TSS in ppm & 66 & 48 & 27.3 & 50 & 15 \\
\hline COD in ppm & 472 & 73.4 & 84.4 & 100 & 50 \\
\hline $\mathrm{BOD}_{5}$ in $\mathrm{ppm}$ & 56 & 10.01 & 82.1 & 30 & 15 \\
\hline $\mathrm{pH}$ & 9.36 & 8.66 & & 6 to 9 & 6 to 9 \\
\hline
\end{tabular}

\footnotetext{
${ }^{a}$ The lowest value of detection for phenol using the analysis method in this paper is $1 \mu \mathrm{g} / \mathrm{L}$. Therefore, the concentration of phenol is less than $2 \mu \mathrm{g} / \mathrm{L}$ (Jordanian norms). ${ }^{\mathrm{b}}$ The lowest value of detection for FOG using the analysis method in this paper is $0.1 \mathrm{ppm}$. Therefore, the concentration of FOG is less than 2 or 8 ppm FOG (Jordanian norms). .
}

Table 4 Best results of treatment of synthetic refinery wastewater using mild steel and SS electrodes at a current of $10 \mathrm{Amp}$, voltage of 27 to 35 , inter-electrode distance of $10 \mathrm{~mm}$, and 10 minutes reaction time

\begin{tabular}{|c|c|c|c|c|c|}
\hline Parameter & $\begin{array}{l}\text { Raw synthetic } \\
\text { wastewater }\end{array}$ & $\begin{array}{c}\text { Treated } \\
\text { wastewater }\end{array}$ & $\begin{array}{c}\% \text { removal of } \\
\text { pollutant }\end{array}$ & $\begin{array}{l}\text { Target value } \\
\text { according to } \\
\text { Jordanian } \\
\text { norms for } \\
\text { using the } \\
\text { treated water } \\
\text { for irrigation of } \\
\text { cooked } \\
\text { vegetables, } \\
\text { parks, } \\
\text { playgrounds }\end{array}$ & $\begin{array}{l}\text { Target value } \\
\text { according to } \\
\text { the most } \\
\text { stringent } \\
\text { Jordanian } \\
\text { norms for } \\
\text { using the } \\
\text { treated water } \\
\text { for cut flowers } \\
\text { irrigation }\end{array}$ \\
\hline
\end{tabular}




\begin{tabular}{|c|c|c|c|c|c|}
\hline $\mathrm{HCO}_{3}$ in ppm & 715.5 & 411 & 42.6 & 400 & 400 \\
\hline $\begin{array}{c}\text { Phenol in } \\
\text { ppm }\end{array}$ & 0.03 & 0.01 & 66.7 & $\begin{array}{c}\text { Less than } \\
0.002\end{array}$ & $\begin{array}{c}\text { Less than } \\
0.002\end{array}$ \\
\hline $\begin{array}{c}\text { TDS in ppm } \\
\begin{array}{c}\text { Fat, oil, and } \\
\text { grease (FOG) } \\
\text { in ppm }\end{array}\end{array}$ & 5210 & 0.10 & 98.8 & 8 & 2 \\
\hline TSS in ppm & 66 & 6.1 & 90.8 & 50 & 15 \\
\hline COD in ppm & 472 & 23.6 & 95.0 & 100 & 50 \\
\hline BOD $_{5}$ in ppm & 56 & 8.4 & 85.0 & 30 & 15 \\
\hline pH & 9.36 & 8.86 & & 6 to 9 & 6 to 9 \\
\hline
\end{tabular}

414

415

416

417

418

419

420

421

422

423

424

425

426

427

428

429

430

431

Both results in Table 3 and 4 have been performed using bipolar electrode configuration. Looking at

Tables 3 and 4 it can be seen that neither of the two electrode combinations at the optimum results was

successful in treating the refinery wastewater so that it would satisfy the most stringent Jordanian

norms. It can be seen that using Al and SS electrodes was successful in producing treated water that could be used for irrigation of cooked vegetables, parks, and playgrounds but not for cut flowers. The experiments using mild steel and SS electrodes did not produce treated water that could be used for irrigating cooked vegetables, parks and playgrounds or cut flowers. For that reason, we are going to concentrate afterwards only on the results relevant to using $\mathrm{Al} / \mathrm{SS}$ electrodes that are also used in our cost calculations.

\subsubsection{Sludge settling tests and production}

Settling tests of the electrocoagulated water (using Al/SS electrodes, a current of $10 \mathrm{Amp}, 28$ to 31 Volt, and 5 minutes reaction time) has been performed in the presence and absence of the flocculating agent the 6691 series of dry PAM cationic ANAFLOC flocculant. Tables 5 and 6 show the settled sludge volume in $\mathrm{mL} / \mathrm{L}$ at a time interval from zero to 30 minutes in the absence and presence of the flocculating agent, respectively.

Table 5 Settling tests of the electrocoagulated water using Al/SS electrodes in the absence of ANAFLOC Time in minutes 


\begin{tabular}{|l|l|}
\hline 10 & 148 \\
\hline 20 & 128 \\
\hline 30 & 120 \\
\hline
\end{tabular}

432

Table 6 Settling tests of the electrocoagulated water using Al/SS electrodes in the presence of ANAFLOC

\begin{tabular}{|c|c|}
\hline Time in minutes & Settled sludge volume in $\mathrm{mL} / \mathrm{L}$ \\
\hline 0 & 1000 \\
\hline 10 & 168 \\
\hline 20 & 160 \\
\hline 30 & 152 \\
\hline
\end{tabular}

Sludge production relevant to the results in Table 3 has been found experimentally using gravimetric methods and was calculated to be $2.9 \mathrm{~kg}$ dry solids per $\mathrm{m}^{3}$ of treated wastewater.

\subsubsection{Percentage dry solids content of sludge after dewatering}

The sludge that resulted from the experiment relevant to Table 3 has been pressed using a lab screw press and the $\%$ dry solids content of the sludge after pressing have been determined gravimetrically and was found to be $25 \%$. A lab screw press has been used in our experiments due to that the screw press and decanter centrifuge have nearly the same cake \% dry solids content after sludge dewatering (Sprick 2017).

\subsection{Power costs of EC treatment plant}

Table 7 shows power costs for the different major equipment in the EC TP in addition to energy consumption in $\mathrm{kWh} / \mathrm{m}^{3}$ or $\mathrm{kWh} /\left(\mathrm{m}^{3} . \mathrm{yr}\right)$ and proportion of costs in \%. For JRWW it turns out to be $1,647,296$ US \$. EC reactors display the highest annual values followed by the decanter centrifuge and $94.7 \%$ of the total of the major equipment used to treat JRWW are for the EC reactors. The EC used in the experiments and at optimum conditions has a power requirement of $15.4 \mathrm{kWh} / \mathrm{kg}$ nonbiodegradable $\mathrm{COD}_{\text {removed. }}$ As an illustration, conventional activated sludge systems can have a power 
453 requirement that can range from 0.85 to $3.33 \mathrm{kWh} / \mathrm{kg}$ COD $_{\text {removed }}$ (Soares et al. 2017). Fig. 2 shows a

454 schematic of the EC TP. First of all in this schematic the mechanically treated JRWW is pumped from

455 large ponds towards EC reactors where the JRWW non-biodegradable COD is $84.4 \%$ removed. Later on,

456 the discharge of treated JRWW from EC reactors is by gravity towards adjacent tanks where the fluid in

457 the latter tanks is pumped to a concrete slurry storage tank. Afterwards the fluid in the concrete tank is

458 pumped to lamella clarifiers where the coagulated pollutants are separated from the water with the

459 help of cationic flocculant pumped from the polymer station to lamella clarifiers. Sludge is discharged by

460 gravity from the two lamella clarifiers to UST from which the sludge is further pumped by a submersible

461 pump to decanter centrifuge. In the decanter centrifuge, the sludge is dewatered by the action of the

462 centrifugal force forming two streams one is the centrate with little solids content and the other is the

463 cake (dewatered sludge) with high solids content.

464

465

466

467

Table 7 Annual power costs for JRWW EC TP major equipment for the year 2022

\begin{tabular}{|c|c|c|c|c|}
\hline Type of equipment & $\begin{array}{c}\text { Power costs (US } \\
\$ / y r)\end{array}$ & $\begin{array}{c}\text { Energy } \\
\text { consumption }\end{array}$ & Unit & $\begin{array}{l}\text { Proportion of } \\
\text { costs (\%) }\end{array}$ \\
\hline Three EC reactors & $1,560,109$ & 6.146 & \multirow{2}{*}{$\mathrm{kWh} / \mathrm{m}^{3}$} & 94.71 \\
\hline Pumps & 29,651 & 0.752 & & 1.80 \\
\hline $\begin{array}{l}\text { Two hydraulic mixing } \\
\text { pumps }\end{array}$ & 6,468 & 193.51 & \multirow{2}{*}{$\mathrm{kWh} /\left(\mathrm{m}^{3} \cdot \mathrm{yr}\right)$} & 0.39 \\
\hline $\begin{array}{l}\text { Two Lamella clarifiers } \\
\text { flash mixers }\end{array}$ & 592 & 96.75 & & 0.036 \\
\hline Polymer station & 3,173 & 2.94 & \multirow{2}{*}{$\mathrm{kWh} / \mathrm{m}^{3}$} & 0.19 \\
\hline Decanter centrifuge & 47,303 & 1.34 & & 2.87 \\
\hline Total & $1,647,296$ & & & \\
\hline
\end{tabular}

468 


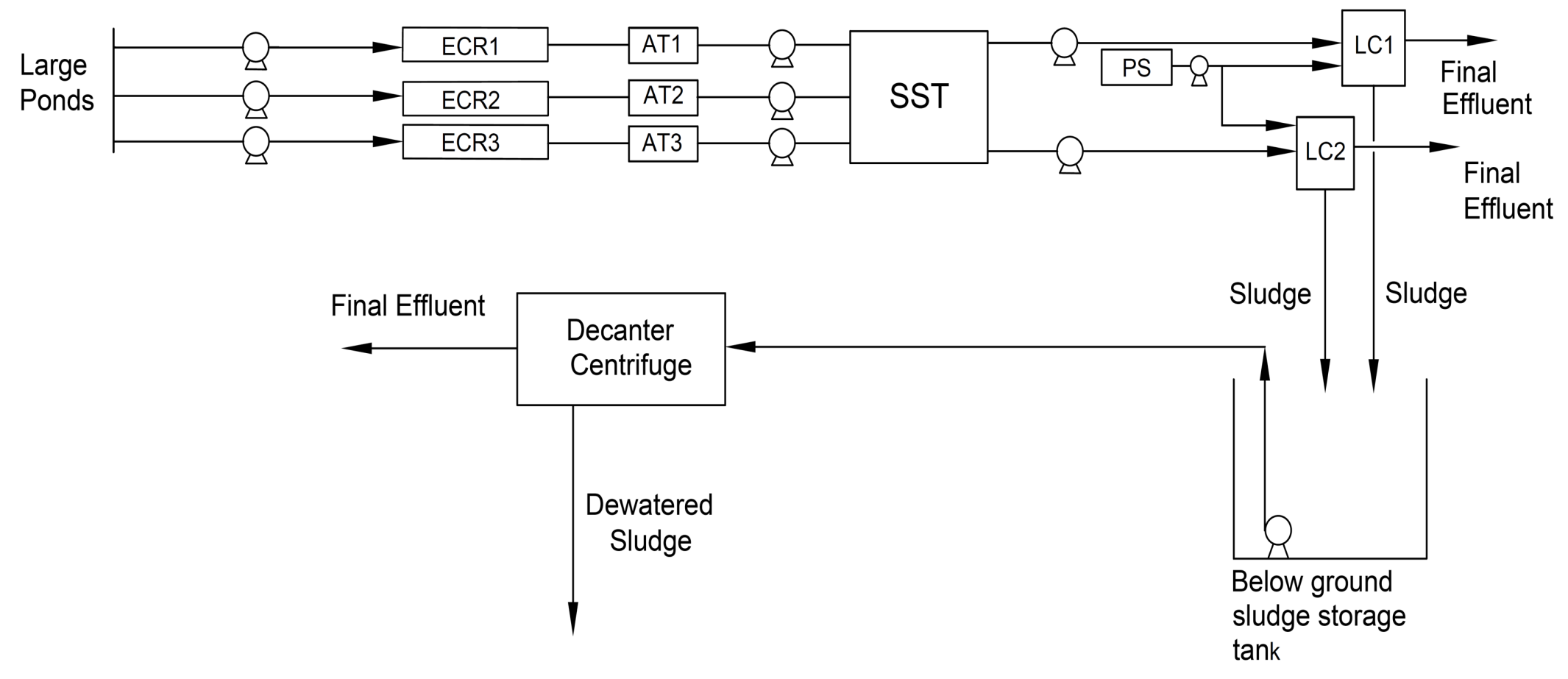

473 Fig. 2 EC TP schematic. Abbreviations are as follows: ECR stands for electrocoagulation reactor, AT stands for adjacent tank, SST stands for slurry 474 storage tank, PS stands for polymer station, LC stands for lamella clarifier. 
477

478

481

\subsection{Costs of the major items of equipment}

\subsection{Annual operating labor costs} to be 147,976 US \$ (year 2022).

Table 8 Annual costs of the raw materials required for the JRWW EC plant for the year 2022

\begin{tabular}{|c|c|c|}
\hline Raw material & Cost (US \$/yr) & Consumption $\left(\mathrm{g} / \mathrm{m}^{3}\right)^{\mathrm{a}}$ \\
\hline ANAFLOC flocculant & 8,732 & 1 \\
\hline Aluminum & 56,544 & 8.6 \\
\hline Stainless Steel & 7,075 & 6.4 \\
\hline Total & 72,351 & \\
\hline
\end{tabular}

\subsection{Dewatered sludge (cake) disposal and treatment costs}

The cake that is transported from Jordan refinery in Zarqa to Russaifah disposal site and treated through land farming has an estimated yearly cost of 2,751,336 US \$ (year 2022).

The yearly labor costs have been estimated based on the daily capacity of the wastewater TP (3836 ton) 
Table 9 displays costs of major items of equipment in the JRWW EC TP in addition to proportions in \%. As can be seen, the EC reactors contribute $44.73 \%$ of the total purchased equipment costs followed by decanter centrifuge and polymer station which is $22.58 \%$.

Table 9 Major items of equipment cost used in the JRWW EC TP for the year 2022

\begin{tabular}{|c|c|c|}
\hline Major equipment & $\begin{array}{c}\text { Purchased and delivered } \\
\text { cost US \$ }\end{array}$ & Proportion of costs (\%) \\
\hline $\begin{array}{c}\text { Three EC reactors } \\
\text { Three feeding pumps to EC } \\
\text { reactors }\end{array}$ & $2,493,057$ & 44.73 \\
\hline Two lamella clarifiers & 23,766 & 0.43 \\
\hline UST & 362,424 & 6.50 \\
\hline $\begin{array}{c}\text { UST hydraulic mixing pump } \\
\text { (HMP) }\end{array}$ & 147,178 & 2.94 \\
\hline Concrete slurry tank & 184,791 & 3.31 \\
\hline Concrete slurry tank HMP & 328,071 & 5.89 \\
\hline $\begin{array}{c}\text { Decanter centrifuge and } \\
\text { polymer station }\end{array}$ & $1,258,576$ & 22.58 \\
\hline Slurry/sludge pumps & 24,611 & 0.44 \\
\hline $\begin{array}{c}\text { Three adjacent tanks to EC } \\
\text { reactors }\end{array}$ & 220,805 & 3.96 \\
\hline Total & $5,573,258$ & 100 \\
\hline
\end{tabular}

\subsection{Overall cost for the treatment of Jordan refinery wastewater using the EC plant}

Table 10 shows the different capital-investment items for a fluid processing plant while Table 11 shows the different annual expense estimates for operating the EC TP. It can be seen that the purchased delivered equipment and service facilities (installed) contribute $35.6 \%$ of the fixed-capital investment while $30.2 \%$ of the total capital investment. As for the yearly operation of the plant, power and sludge disposal/treatment contribute about $37.6 \%$ (highest contributor) of the annual operating cost and is followed by maintenance and repairs of $13.6 \%$. The overall cost for JRWW wastewater treatment is 10.75 US $\$ / \mathrm{m}^{3}$ (26.97 US $\$ / \mathrm{kg}$ non-biodegradable COD removed $_{\text {). }}$ 
511 Table 10 Different capital-investment items costs for a solid-fluid processing plant based on delivered-

512 equipment cost

\begin{tabular}{|c|c|c|}
\hline Item & Capital cost in US \$ & $\begin{array}{c}\text { Percentage of } \\
\text { delivered equipment } \\
\text { cost }\end{array}$ \\
\hline Purchased equipment-delivered & $5,573,258$ & 100 \\
\hline Purchased-equipment installation & $2,619,431$ & 47 \\
\hline Instrumentation and controls (installed) & $1,003,186$ & 18 \\
\hline Piping (installed) & $3,678,350$ & 66 \\
\hline Electrical (installed) & 613,058 & 11 \\
\hline Buildings (including services) & $1,003,186$ & 18 \\
\hline Yard improvements & 557,326 & 10 \\
\hline Service facilities (installed) & $3,901,281$ & 70 \\
\hline Engineering and supervision & $1,839,175$ & 33 \\
\hline Construction expenses & $2,285,036$ & 41 \\
\hline Contractor's fee & $1,170,384$ & 21 \\
\hline Contingency & $2,340,768$ & 42 \\
\hline Fixed-capital investment & $26,584,440$ & 477 \\
\hline Working capital & $4,739,002$ & 86 \\
\hline Total capital investment & $31,377,442$ & 563 \\
\hline
\end{tabular}

513

Table 11 Different expense estimates that includes operating cost in US \$/yr and overall cost for wastewater treatment

\begin{tabular}{|c|c|}
\hline Expense & EC plant expenses \\
\hline \multicolumn{2}{|l|}{ I -Manufacturing costs } \\
\hline \multicolumn{2}{|l|}{ A. Direct production costs, US $\$ / \mathrm{yr}$} \\
\hline 1-Raw materials, US $\$ / y r$ & $72,350.5$ \\
\hline 2-Operating labor, US $\$ / y r$ & 147,976 \\
\hline 3-Operating supervision, US $\$ / y r$ & 25,896 \\
\hline 4-Power and sludge disposal/treatment, US \$/yr & $4,398,632$ \\
\hline 5-Maintenance and repairs, US \$/yr & $1,595,066$ \\
\hline 6-Operating supplies, US $\$ / y r$ & 239,260 \\
\hline 7-Laboratory charges, US $\$ / \mathrm{yr}$ & 22,196 \\
\hline \multicolumn{2}{|l|}{ B. Fixed charges, US \$/yr } \\
\hline 1-Taxes, US \$/yr & 664,611 \\
\hline 2-Insurance, US $\$ / y r$ & 186,091 \\
\hline 3-Depreciation, US \$/yr & $1,329,222$ \\
\hline C. Plant overhead costs, US $\$ / \mathrm{yr}$ & $1,061,363$ \\
\hline \multicolumn{2}{|l|}{ II- General Expenses } \\
\hline 1.Administrative expenses, US \$/yr & 36,994 \\
\hline 2.Financing, US $\$ / y r$ & $1,568,872$ \\
\hline III -Total production cost, US $\$ / \mathrm{yr}$ & $11,348,530$ \\
\hline
\end{tabular}


516

517

518

519

520

521

522

523

524

525

526

527

528

529

530

531

532

533

534

535

536

537

\begin{tabular}{|c|c|}
\hline Contingencies, US $\$ / \mathrm{yr}$ & 340,456 \\
\hline Operating cost, US $\$ / \mathrm{yr}$ & $11,688,986$ \\
\hline Overall cost, US $\$ \mathrm{~m}^{3}$ & 10.75 \\
\hline Overall cost, US $\$ /$ g non-biodegradable COD removed & 26.97 \\
\hline
\end{tabular}

\section{Discussion}

\subsection{Experimental results}

\subsubsection{Removal of phenol}

The experiments of EC at optimum conditions in this work using $\mathrm{Al} / \mathrm{SS}$ electrodes managed to remove phenol to a high percentage (at least $96.7 \%$ ). El-Ashtoukhy et al. 2013 studied the removal of phenol from petroleum refinery wastewater. They found that operating an EC reactor at optimum conditions $\left(\mathrm{pH}=7\right.$, Current density $=8.59 \mathrm{~mA} / \mathrm{cm}^{2}, \mathrm{NaCl}=1 \mathrm{~g} / \mathrm{L}$, Temperature $\left.=25^{\circ} \mathrm{C}\right)$ using Al material as anode and cathode managed to completely remove phenol (100\% removal) from a phenol synthetic solution that had an initial phenol concentration of $5 \mathrm{mg} / \mathrm{L}$ in a period of 30 minutes. In our experiments we managed to remove at least $96.7 \%$ of the phenol from synthetic wastewater that had an initial phenol concentration of $0.03 \mathrm{mg} / \mathrm{L}$ at optimum conditions in a period of 5 minutes. The much shorter reaction time required in our case could be explained by the much lower initial concentration of phenol in the synthetic wastewater. El-Ashtoukhy et al. 2013 found that by operating the EC reactor at specified conditions and by increasing the initial concentration of phenol solution that is subjected to EC causes a decrease in the removal percentage of phenol from 100 to $75 \%$. Moreover, a higher current density of 268.2 A/ $\mathrm{m}^{2}$ was used in our experiment at optimum conditions than that of El-Ashtoukhy's et al. 2013 $\left(85.9 \mathrm{~A} / \mathrm{m}^{2}\right)$ which contributes to more dissolution of Al and SS (iron) electrodes according to Faraday's law and the ions of $\mathrm{Al}$ and $\mathrm{Fe}$ undergo hydrolysis producing $\mathrm{Al}$ and Fe hydroxides on which phenol is adsorbed and more of this compound is removed in our case in a shorter reaction time (El-Ashtoukhy et al. 2013, Tanyol et al. 2018). Table 12 shows further comparisons of this work results with Bazrafshan's 
and Zazouli's outcomes. It can be seen that we had a shorter treatment time to achieve a similar phenol removal percentage at a higher current than that of Bazrafshan's and a current density close to that of Zazouli et al. 2012.

Table 12 Bazrafshan's and Zazouli's results compared to the present work

\begin{tabular}{|c|c|c|c|c|}
\hline $\begin{array}{c}\text { Electrode } \\
\text { material }\end{array}$ & $\begin{array}{c}\text { Current density in } \\
\mathrm{A} / \mathrm{m}^{2} \text { (current in A) }\end{array}$ & $\begin{array}{c}\text { Treatment time } \\
\text { (minutes) }\end{array}$ & Phenol removal \% & References \\
\cline { 1 - 4 } $\mathrm{Al}$ & $(5)$ & 80 & 94.72 & \multirow{2}{*}{$\begin{array}{c}\text { Bazrafshan et al. } \\
2012\end{array}$} \\
\cline { 1 - 4 } $\mathrm{Fe}$ & 250 & 60 & 98 & $\begin{array}{c}\text { Zazouli et al. } \\
2012\end{array}$ \\
\cline { 1 - 4 } $\mathrm{Al}$ & $268.2(10)$ & 5 & At least 96.7 & This work \\
\hline Al plus Fe & & &
\end{tabular}

\subsubsection{Removal of FOG}

FOG percentage removal in this work at optimum conditions was at least $98.8 \%$ using $\mathrm{Al} / \mathrm{SS}$ electrodes for an initial FOG concentration of $8.5 \mathrm{mg} / \mathrm{L}$. Changmai et al. 2019 reported the best percentage of oil and grease removal from a drilling site oily wastewater as $70.9 \%$ (initial oil and grease concentration is $35 \mathrm{mg} / \mathrm{L}$ ) through EC using aluminium material as anode and cathode at a $\mathrm{pH}$ of 3.6, current density of $80 \mathrm{~A} / \mathrm{m}^{2}$, inter-electrode distance of $0.5 \mathrm{~cm}$, and a treatment time of 20 minutes. Liu et al. 2019 studied the oil removal percentage from simulated produced water relevant to oilfields through EC using Aluminium (anode) and iron (cathode) electrodes. At optimum conditions ( $\mathrm{pH}=7$, current density $=40$ $\mathrm{A} / \mathrm{m}^{2}$, treatment time $=28$ minutes) they removed $70.2 \%$ of the oil. GilPavas et al. 2009 reported the treatment of oily wastewater from automotive industry through EC using iron/aluminium as anode/cathode and vice versa. At optimum conditions (Fe as anode, $\mathrm{pH}=12$, current density $=43 \mathrm{~A} / \mathrm{m}^{3}$, treatment time $=180$ minutes) $98.6 \%$ of oil was removed. Drogui et al. 2009 reported $90 \%$ oil\& grease removal from oily ship effluents through EC using Al electrodes in bipolar configuration at optimum conditions (Current $=0.3 \mathrm{~A}, \mathrm{pH}=7.1$, treatment time $=60$ minutes). Compared to all the aforementioned 
558 works this work had a higher FOG removal percentage at a shorter reaction time and a higher current

559 intensity (10 A) or density $\left(268.2 \mathrm{~A} / \mathrm{m}^{2}\right)$.

560

561

\subsubsection{Removal of COD}

562 Table 13 shows the removal of COD in this work compared to other literature work. As can be seen from

563 Table 13 the removal \% of COD of this work is compatible with the other COD removal percentages and

564 is achieved at a higher current intensity or density and a reaction time same as Ozyonar 2016, less than

565 GilPavas et al. 2009/ Drogui et al. 2009, and higher than Gomes et al. 2009.

566

567 Table 13 COD removal of this work compared to other literature work

\begin{tabular}{|c|c|c|c|c|c|c|}
\hline $\begin{array}{c}\text { Electrode } \\
\text { material }\end{array}$ & $\begin{array}{c}\text { Current } \\
\text { density in } \\
\mathrm{A} / \mathrm{m}^{2} \\
\text { (current in } \mathrm{A} \text { ) }\end{array}$ & $\begin{array}{c}\text { Type of } \\
\text { wastewater }\end{array}$ & $\begin{array}{c}\text { Electrode } \\
\text { configuration }\end{array}$ & $\begin{array}{l}\text { Treatment } \\
\text { time in } \\
\text { minutes }\end{array}$ & $\begin{array}{c}\text { COD } \\
\text { removal \% }\end{array}$ & References \\
\hline $\begin{array}{l}\text { Al plus Fe } \\
\text { (hybrid) }\end{array}$ & (1.57) & $\begin{array}{c}\text { Train } \\
\text { industry } \\
\text { oily } \\
\text { wastewater }\end{array}$ & Bipolar (BP) & 5 & 92.6 & $\begin{array}{c}\text { Ozyonar } \\
2016\end{array}$ \\
\hline $\begin{array}{l}\text { Al plus Fe } \\
\text { (hybrid) }\end{array}$ & 43 & $\begin{array}{l}\text { Automotive } \\
\text { industry } \\
\text { oily } \\
\text { wastewater }\end{array}$ & $\mathrm{BP}$ & 180 & 67 & $\begin{array}{c}\text { GilPavas et } \\
\text { al. } 2009\end{array}$ \\
\hline Al & (0.3) & $\begin{array}{l}\text { Oily ship } \\
\text { effluents }\end{array}$ & $\mathrm{BP}$ & 60 & 69.1 & $\begin{array}{l}\text { Drogui et } \\
\text { al. } 2009\end{array}$ \\
\hline $\mathrm{Fe}$ & \multirow{2}{*}{200} & \multirow{2}{*}{$\begin{array}{c}\text { Produced } \\
\text { water }\end{array}$} & $\mathrm{BP}$ & \multirow{2}{*}{1.7} & 82.9 & \multirow{2}{*}{$\begin{array}{l}\text { Gomes et } \\
\text { al. } 2009\end{array}$} \\
\hline $\mathrm{Al}$ & & & $\mathrm{BP}$ & & 74.1 & \\
\hline $\begin{array}{l}\text { Al plus Fe } \\
\text { (hybrid) }\end{array}$ & $268.2(10)$ & $\begin{array}{c}\text { Synthetic } \\
\text { refinery } \\
\text { wastewater }\end{array}$ & BP & 5 & 84.4 & This work \\
\hline
\end{tabular}

568

$569 \quad$ 6.1.4 Removal of BOD

570 After searching the literature there is only the work of Drogui et al. 2009 that measured the removal of

571 BOD in oily ship effluents (oily wastewater) through EC using Al electrodes in BP configuration. They

572 found that at a current of $0.3 \mathrm{~A}$ and a treatment time of 60 minutes (optimum conditions) $89.4 \%$ of the 
573 BOD was removed. This work achieved a BOD removal of $82.1 \%$ at optimum conditions which is

574 compatible with the work of Drogui et al. 2009.

575

$576 \quad$ 6.1.5 Removal of TSS

577 There were two works found in literature (Sardari 2018, Drogui et al. 2009) who measured the TSS 578 removal from oily wastewater after EC treatment in bipolar configuration. Sardari 2018 treated 579 produced water using Aluminium electrodes and at a current of $3 \mathrm{~A}$ and a treatment time of 30 seconds 580 and achieved a TSS removal of $91 \%$. Drogui et al. 2009 reported $31.5 \%$ TSS removal from oily ship 581 effluents using Aluminium electrodes at a current of $0.3 \mathrm{~A}$ and a treatment time of 60 minutes. This 582 work achieved a TSS removal of $27.3 \%$.

6.1.6 $\mathrm{pH}$

585 Raw synthetic wastewater in this work had an initial pH above 9 (Table 3 ) and after finishing the EC the $586 \mathrm{pH}$ of the treated wastewater reduced to 8.66 which is within the range of the $\mathrm{pH}$ norms required to use 587 the treated wastewater for irrigation. The decrease in $\mathrm{pH}$ could be explained by the reaction of 588 aluminum hydroxide precipitates $\mathrm{Al}(\mathrm{OH})_{3}$ with the hydroxyl ions generated during $\mathrm{EC}$ which leads to the 589 consumption of hydroxyl ions as shown by the following reaction (Chen 2004):

590

591

$$
\mathrm{Al}(\mathrm{OH})_{3}+\mathrm{OH}^{-} \rightarrow \quad \mathrm{Al}(\mathrm{OH})_{4}^{-}
$$

$592 \quad 6.1 .7$ Removal of bicarbonate

593 This work at optimum conditions has a bicarbonate removal of $94.9 \%$. There wasn't any work in 594 literature that studied the removal of bicarbonate in oily wastewater through EC in bipolar configuration 595 to compare with.

596 6.1.8 Sludge settling tests and its volume index 
597 The sludge volume index (SVI) is defined as the volume occupied by one gram of sludge after 30 minutes

598 settling time (Mohlman 1934). It was originally intended to be a rough measure of sludge settleability to 599 be used in everyday operation of wastewater treatment plants. Moreover, SVI is an important 600 parameter for clarifiers since it provides an insight in obtaining a clear effluent from the clarifier without 601 significant carryover of sludge with it. The SVI has been computed for the results in Table 5 and 6 to be 60241.4 and $52.4 \mathrm{~mL} / \mathrm{g}$, respectively. It is reported in literature that a good SVI value for sludge should be 603 below $100 \mathrm{~mL} / \mathrm{g}$ (Diya'uddeen et al. 2015) and in our case it means that the sludge has good settling and 604 compaction properties whether in the absence or presence of ANAFLOC. The flocs formed during the 605 settleability tests conducted on treated synthetic refinery wastewater by electrocoagulation using $\mathrm{Al} / \mathrm{SS}$ electrodes were of white color and there was a clear solids-liquid separation at 10 minutes of settling 607 time whether polyacrylamide (PAM) cationic flocculant Anafloc 6691 was used or not but the use of the 608 polymer flocculating agent (at a concentration of $0.001 \mathrm{gram} / \mathrm{l}$ ) resulted in more solids sedimentation and resulted in a larger value of SSV30 $(152 \mathrm{~mL} / \mathrm{L})$. Therefore, the results of Table 6 are used when computing the $\%$ dry solids in sludge before dewatering.

\subsubsection{Pollutant removal capacity}

613 The pollutant removal capacity has been estimated based on the method of Kobya et al. 2015 and are

614 shown in Table 14. As can be seen the highest removal capacity was for bicarbonate followed by COD.

615 Table 14 Pollutant removal capacities relevant to using Al/SS electrodes

\begin{tabular}{|c|c|c|}
\hline Pollutant & $\begin{array}{c}\text { g pollutant removed/g hybrid } \\
\text { metal }(\mathrm{HM})\end{array}$ & mg pollutant removed/Coulomb \\
\hline COD & 26.6 & 0.53 \\
\hline BOD & 3.1 & 0.06 \\
\hline TSS & 1.2 & 0.02 \\
\hline Phenol & At least 0.002 & At least $3.87 \times 10^{-5}$ \\
\hline Bicarbonate & 45.2 & 0.90 \\
\hline FOG & At least 0.6 & At least 0.01 \\
\hline
\end{tabular}


$617 \quad 6.2$ Costs

618 The goal of the economic evaluation here is not to provide a comprehensive financial analysis but to 619 have an order of magnitude estimate of the capital and operating costs which would be approximate. It 620 was a preliminary economic evaluation which is partially based on experimental bench-scale data which 621 were conducted and shown previously in this manuscript. The capital cost of the whole plant in this 622 study was estimated based on ratio factors for a fluid processing plant (Peters and Timmerhaus 1991). In

623 this study the method is based on estimating the purchase price (including delivery) of major equipment 624 either using cost equations from reports/books or obtaining it directly from vendors. The total sum of 625 major delivered equipment cost is further multiplied by ratio factors in order to know approximately the 626 capital cost required to put the wastewater treatment plant into operation. The sum of major delivered 627 equipment cost has a value of $5,573,258$ US $\$$.

628 The operating cost items operating labor, raw materials, power, and sludge management expense 629 estimation was not based on percentages (e.g. for example maintenance and repairs was 2 to $10 \%$ of 630 the fixed capital investment) but involved using equations, data, quotes, and Jordanian hourly wage 631 rate. The labor cost was calculated based on a Jordanian hourly wage rate of 1.62 US \$/man-hour and 632365 operating days per year. Estimated power consumption (electrical) relevant to mixing and pumping 633 is $237,481 \mathrm{kWh} / \mathrm{yr}$. In case of power consumption relevant to electrocoagulation reactors we have based 634 our calculations on bench-scale experimental data. The voltage and current during electrocoagulation 635 experiments that resulted in $\mathrm{COD}, \mathrm{BOD}, \mathrm{TSS}, \mathrm{FOG}$. phenol, and $\mathrm{HCO}_{3}$ removals such that the treated 636 effluent concentrations of the previous parameters are at or below the Jordanian norms required for its 637 possible use for irrigation was $29.5 \mathrm{~V}$, and $10 \mathrm{~A}$, respectively. The unit electricity requirement for EC 638 reactors is $6.15 \mathrm{kWh} / \mathrm{m}^{3}$.

639 Sludge resulting from petroleum refinery wastewater treatment is considered as hazardous (US EPA 640 2012) and in this manuscript it is treated through land farming which is a bioremediation technique. 
641 Land-farming has advantages such as low cost of operation, supports large scale treatment, and has a

642

643

644

645

646

647

648

649

650

651

652

653

654

655

656

657

658

high potential for success (Johnson and Affam 2019, Marin et al. 2005). Moreover, it is a widely employed land treatment approach (Hu et al. 2013). A typical cost for this hazardous waste treatment through land-farming is 30 to 60 US $\$ /$ ton of contaminated soil (US EPA 1995). It is assumed that the land used for bioremediation is in the vicinity of Russaifah disposal site. Estimated costs for sludge disposal and treatment in this study is $2,751,336 \$ / \mathrm{yr}$ (year 2022).

The overall cost for wastewater treatment at full-scale in this work was estimated as $10.75 \mathrm{US} \$ / \mathrm{m}^{3}$ (27 US $\$ / \mathrm{kg}$ COD $_{\text {removed }}$ ) considering a service life of 20 years of all major items of equipment in the EC TP. Full-scale plants using EC are present in the USA and Australia treating different kinds of wastewater. Tetreault (2003) reported a slaughterhouse in Australia that used EC technology at full-scale for the treatment of a mixture of stick and blood water $\left(6.5 \mathrm{~m}^{3} / \mathrm{hr}\right)$. Eames et al (2017) reported silica removal in mineral mining/processing and oil/gas extraction wastewaters at full-scale using a treatment train that included EC. Table 15 shows a comparison between this work treatment costs with other works from literature. It can be seen that this work treatment costs is of the same order of magnitude as that of Eames et al. (2017) but an order of magnitude higher that Tetreault (2003). Therefore, the cost figure of this work is reasonable.

Table 15 Comparisons of treatment costs through EC of this work result with other works from literature that also used EC for treating their wastewater at full-scale

\begin{tabular}{|c|c|c|c|}
\hline Type of wastewater & $\begin{array}{c}\text { Flow rate } \\
\left(\mathrm{m}^{3} / \mathrm{hr}\right)\end{array}$ & $\begin{array}{c}\text { Treatment costs in } \\
\text { US } \$ / \mathrm{m}^{3}(2022)\end{array}$ & References \\
\hline Stick/blood wastewater & 6.5 & $0.77^{a}$ & Tetreault (2003) \\
\hline $\begin{array}{c}\text { Mineral } \\
\text { mining/processing } \\
\text { wastewater }\end{array}$ & 22.7 & $2.56^{b}$ & \multirow[t]{2}{*}{ Eames et al. (2017) } \\
\hline $\begin{array}{l}\text { Oil/gas extraction } \\
\text { wastewater }\end{array}$ & 165.6 & $3.47^{c}$ & \\
\hline \multirow{3}{*}{$\begin{array}{c}\text { Petroleum refinery } \\
\text { wastewater }\end{array}$} & \multirow{3}{*}{160} & $3.62^{d}$ & \multirow{3}{*}{ This work } \\
\hline & & $3.63^{e}$ & \\
\hline & & $3.74^{f}$ & \\
\hline
\end{tabular}

aThis number has been estimated based on data from Tetreault (2003) which included metal and power consumption as the only operating 660 costs ${ }^{\mathrm{b}}$ This number has been estimated based on data from Eames et al. (2017) which included power, chemicals, and metal consumption as 661 
662

663

664

665

666

667

668

669

670

671

672

673

674

675

676

677

consumables as the only operating costs ${ }^{\mathrm{d} C o n s i d e r i n g ~ o n l y ~ m e t a l ~ a n d ~ p o w e r ~ c o n s u m p t i o n ~ a s ~ t h e ~ o p e r a t i n g ~ c o s t s ~ f o r ~ c o m p a r i n g ~ w i t h ~ s t i c k / b l o o d ~}$ slaughterhouse wastewater treatment costs of Tetreault (2003) e'Considering only power, chemicals, and metal consumption as the operating costs for comparing with mineral mining/processing wastewater treatment costs of Eames et al. (2017) fConsidering only power, labor, and treatment consumables as the operating costs for comparing with oil/gas extraction wastewater treatment costs of Eames et al. (2017)

Main items of equipment in the full plant considered here consist of EC reactors, lamella clarifiers, decanter centrifuge, polymer station, and auxiliary equipment such as pumps and tanks. Prices of main equipment that were obtained directly from vendors are for example costs of Lamella clarifiers, and slurry/sludge pumps. Further sources are equations deduced from published cost data in reports/books such as cost of EC reactors, UST, UST HMP, concrete slurry tank, concrete slurry tank HMP, decanter centrifuge/polymer station, and adjacent tanks to EC reactors. Moreover, different indices have been applied in order to update the costs of equipment to the year 2022 which is assumed as the opening year of the EC TP. These cost indices are specifically the Marshal and Swift equipment, Chemical Engineering Plant, and Engineering News Record Construction Cost indices. The initial and updated values of the cost indices used are shown in Table 16.

Table 16 Initial and update values of the cost indices used in this work

\begin{tabular}{|c|c|c|c|c|c|c|}
\hline \multirow[t]{2}{*}{ Equipment } & \multicolumn{2}{|c|}{$\begin{array}{l}\text { Marshall \& Swift } \\
\text { equipment cost index }\end{array}$} & \multicolumn{2}{|c|}{$\begin{array}{l}\text { Chemical Engineering } \\
\text { Plant cost index }\end{array}$} & \multicolumn{2}{|c|}{$\begin{array}{l}\text { Engineering News } \\
\text { Record Construction } \\
\text { cost index }\end{array}$} \\
\hline & Initial & Updated $^{f}$ & Initial & Updated $^{f}$ & Initial & Updated $^{f}$ \\
\hline $3 \mathrm{EC}$ reactors & $1,274.8^{\mathrm{a}}$ & 1878.39 & -- & -- & -- & -- \\
\hline $\begin{array}{c}3 \text { feeding pumps to EC } \\
\text { reactors }\end{array}$ & -- & -- & 389.5 & 685.66 & -- & -- \\
\hline 2 Lamella clarifiers & $1735.78^{b}$ & 1878.39 & & & & \\
\hline UST & -- & -- & -- & -- & $4006^{c}$ & 11971 \\
\hline UST HMP & \multirow[b]{2}{*}{$751^{c}$} & \multirow[b]{2}{*}{1878.39} & -- & -- & -- & -- \\
\hline $\begin{array}{c}\text { Concrete slurry tank } \\
\text { HMP }\end{array}$ & & & -- & -- & -- & -- \\
\hline Sludge pump & $1828.63^{d}$ & \multirow{2}{*}{1878.39} & -- & -- & -- & -- \\
\hline Slurry pumps & $1781.13^{\mathrm{e}}$ & & -- & -- & -- & -- \\
\hline $\begin{array}{c}\text { Decanter } \\
\text { centrifuge/Polymer } \\
\text { station }\end{array}$ & -- & -- & -- & -- & $8586^{h}$ & 11971 \\
\hline Concrete slurry tank & -- & -- & \multirow[b]{2}{*}{$325.8^{g}$} & \multirow[b]{2}{*}{685.66} & -- & -- \\
\hline $\begin{array}{c}\text { Adjacent tanks to EC } \\
\text { reactors }\end{array}$ & -- & -- & & & -- & -- \\
\hline
\end{tabular}


678

679

680

681

682

683

684

685

686

687

688

689

690

691

692

693

694

695

696

697

698

699

700

701

${ }^{a}$ Annual average value for the year $2006{ }^{b}$ Annual average value for the year 2019, cMarch, 1983, dAnnual average value for the year $2021 \mathrm{e}$

Annual average value for the year 2020, fupdated values are annual average values for the year 2022, gOctober, 1985, hSeptember, 2009.

The ratio factors mentioned in Table 10 are used for estimating the capital cost of a fluid processing plant such as distillation units, water and wastewater treatment plants (Awad and Abuzaid 1997). Since we are dealing with a wastewater treatment plant in this study, the factors in Table 10 for a fluid processing plant have been selected. The EC TP for JRWW $\left(160 \mathrm{~m}^{3} / \mathrm{hr}\right)$ had an estimated total capital investment and annual operating cost of $31,377,442$ and $11,668,986$ US $\$$, respectively. For comparison, a conventional activated sludge system treating on average $200 \mathrm{~m}^{3} / \mathrm{hr}$ of domestic wastewater can have a construction and annual operating cost of about $12,500,000$ and 500,000 US $\$$ for the year 2016 , respectively (Jafarinejad 2017). Using a conventional activated sludge process to compare the capital and operating costs to our system is because activated sludge is the most widely applied biological treatment of liquid waste, whether originating from industrial processes or households (Jafarinejad 2017). Moreover, biological treatment processes are very economical and efficient options when compared to chemical and physical treatment methods (Li 2013). The capital costs of the two treatment systems are of the same order of magnitude but operating costs for the EC TP are two orders of magnitude higher. This comparison suggests that the EC treatment technique is a viable option for JRWW. Jordan refinery can finance such a project since its profit is about two times larger than the estimated total capital investment of the potential EC TP. The profit of Jordan refinery for the year 2018 is 36.9 million Jordanian Dinars which is about 52 million US \$ (Jordan Refinery Company annual report 2018). The total capital investment has been estimated based on brand new purchased delivered equipment. Substantial reduction in total capital investment can be achieved if second hand equipment is used, though the service life of this equipment may be shorter. Total capital investment reductions will also reduce several expense estimation items relevant to operating costs resulting in lowering the overall cost for JRWW treatment. Additionally, if Jordan refinery has excess electrical energy enough to 
702 power the EC reactors (main user of electricity) and other equipment the operating costs will also go 703 down and with it overall cost of JRWW treatment.

$704 \quad J R W W$ has a BOD/COD ratio $<0.3$ and renders the wastewater biologically untreatable (Srinivas 705 2008) because it inhibits the metabolic action of bacteria due to the refractory and/or toxicity property 706 of this water (Abdalla and Hammam 2014). Thus, the COD removed using the EC reactors would be the 707 non-biodegradable COD.

708

7097 Conclusions

710 In order to meet the increasing water demands in arid and semi-arid regions such as Jordan one of the 711 options is to reclaim wastewater and in this article it was industrial. The treatment of waste effluents is 712 continuing to be a fundamental issue in the majority of industries. There are many companies 713 worldwide who spend a large sum of money in order to treat the hazardous substances in their 714 effluents. Unfortunately, it is with high probability that refining industries in the MENA region do not 715 treat their effluents properly and Jordan is no exception as has been mentioned in this study. This study 716 outlined a process that can be used to treat refinery effluent. Detail of chemical and equipment 717 requirements as well as the costs relevant to such a process has been presented. The technology used to 718 reclaim refinery wastewater in this study was electrocoagulation which is an enigmatic technology and 719 we still do not know its full potential. Based on available literature there are only few companies that 720 applied this technology on full scale and the results of this research would be encouraging for 721 companies to apply such technology in the future for their industrial effluents. The overall cost for 722 treatment using EC technology may be high (as has been shown in this manuscript) but future 723 technological development in the EC technology will probably reduce overall costs further which may 724 cause this technology to be applied on a wider scale. Third-world countries lack suitable infrastructure 725 and required capital investments for WW treatment plants (Borghe-ei et al. 2015). They require 
726

727

728

729

730

731

732

733

734

735

736

737

738

739

740

741

742

743

744

745

746

747

748

749

wastewater treatment technologies that can be easily operated, has minimal operation/maintenance capital expenditure and skilled labor. The EC technology has all the aforementioned characteristics and can be considered as an option to be employed for the treatment of refineries wastewater emitted in the MENA region in exchange for a reasonable cost. Jordan refinery wastewater was treated successfully to conform to Jordanian norms of COD, BOD, TSS, FOG, phenol, and bicarbonate so that it could be used for irrigation or as a possible source of de-salter wash-water. Irrigation could be for parks, playgrounds or plants that are grown for their fiber (e.g. cotton). So, it is a suitable technology for the treatment of JRWW and the cost for its treatment is affordable.

\section{Declarations}

Funding the authors have no relevant financial or non-financial interests to disclose.

Conflicts of interest the authors have no conflicts of interest to declare that are relevant to the content of this article.

Availability of data and material All data generated or analysed during this study are included in this published article (and its supplementary information files).

Code availability not applicable

Authors' contributions All authors contributed to the study conception and design. Material preparation, data collection and analysis were performed by Simon R Sakhel and Sven-Uwe Geissen. The first draft of the manuscript was written by Simon R Sakhel and all authors commented on previous versions of the manuscript. All authors read and approved the final manuscript. 


\section{References}

751 Abdalla KZ, Hammam G (2014) Correlation between Biochemical Oxygen Demand and Chemical Oxygen

752 Demand for Various Wastewater Treatment Plants in Egypt to Obtain the Biodegradability Indices. 753 IJSBAR 13 (1): 42-48.

754

755 Abdelwahab O, Amin NK, El-Ashtoukhy ESZ (2009) Electrochemical removal of phenol from oil refinery 756 wastewater. J Hazard Mater 163 (2-3): 711-716. https://doi.org/10.1016/j.jhazmat.2008.07.016

757

758

Akyol A (2012) Treatment of paint manufacturing wastewater by electrocoagulation. Desalination 285 :

759

91-99. https://doi.org/10.1016/i.desal.2011.09.039

760

761

Al-Khalid T, El-Naas MH (2018) Organic Contaminants in Refinery Wastewater: Characterization and

762 Novel Approaches for Biotreatment. In: Zoveidavianpoor M. (ed.) Recent Insights in Petroleum Science 763 and Engineering. IntechOpen Limited, London, pp 371-391.

764

765 Al-Qodah Z, Al-Qudah Y, Omar W (2019) On the performance of electrocoagulation-assisted biological

766 treatment processes: a review on the state of the art. Environ Sci Pollut Res 26 (28): 28689-28713.

767 https://doi.org/10.1007/s11356-019-06053-6

768

769 Asselin M, Drogui P, Brar SK, Benmoussa H, Blais JF (2008) Organics removal in oily bilgewater by 770 electrocoagulation process. J Hazard Mater $151 \quad$ (2-3): 446-455. 771 https://doi.org/10.1016/i.jhazmat.2007.06.008

772 
773 Awad YM, Abuzaid NS (1997) Electrochemical treatment of phenolic wastewater: Efficiency, design

774 considerations and economic evaluation. J Environ Sci Health A32(5): 1393-1414.

775 https://doi.org/10.1080/10934529709376617

776

777 Aygun A, Nas B, Sevimli MF (2019) Treatment of reactive dyebath wastewater by electrocoagulation

778 process: Optimization and cost-estimation. Korean J Chem Eng 36 (9): 1441-1449.

779 https://doi.org/10.1007/s11814-019-0334-7

780

781 Bassala HD, Dedzo GK, Baudouin C, Bememba N, Seumo PMT, Dazie JD, Nanseu-Njiki CP, Ngameni E

782 (2017) Investigation of the efficiency of a designed electrocoagulation reactor: Application for dairy

783 effluent treatment, Process Saf Environ Prot 111: 122-127.

784 http://dx.doi.org/10.1016/j.psep.2017.07.002

785

786 Bazrafshan E, Biglari H, Mahvi AH (2012) Phenol removal by electrocoagulation process from aqueous 787 solutions. Fresenius Environ Bull 21 (2): 364-371.

788

789 Borghe-ei SM, Goodarzi J, Mohseni M, Amouei A (2015) Efficiency of Removing Chromium from Plating 790 Industry Wastewater using the Electrocoagulation Method. Int Arch Health Sci 2(2):83-87.

791

792 Calvo LS, Leclerc JP, Tanguy G, Cames MC, Paternotte G, Valentin G, Rostan A, Lapicque F (2003) An

793 Electrocoagulation Unit for the Purification of Soluble Oil Wastes of High COD. Environ Prog 22 (1): 57-

794 65. https://doi.org/10.1002/ep.670220117

795 
796 Cañizares P, Paz R, Sáez C, Rodrigo MA (2009) Costs of the electrochemical oxidation of wastewaters: A

797 comparison with ozonation and Fenton oxidation processes. J Environ Manage 90 (1): 410-420.

798 https://doi.org/10.1016/i.jenvman.2007.10.010

799

800 Celenza GJ (2000) Industrial Waste Treatment Process Engineering: Volume III Specialized Treatment 801 System, TECHNOMIC PUBLISHING CO, INC, Lancaster, Pennsylvania, USA.

802

803 Changmai M, Pasawan M, Purkait MK (2019) Treatment of oily wastewater from drilling site using 804 electrocoagulation followed by microfiltration. Sep Purif Technol 210: 463-472. 805 https://doi.org/10.1016/j.seppur.2018.08.007

806

807 Chauhan R, Srivastava VC, Hiwarkar AD (2016) Electrochemical mineralization of chlorophenol by 808 ruthenium oxide coated titanium electrode, J Taiwan Inst Chem E 69: 106-117.

809 https://doi.org/10.1016/i.jtice.2016.10.016

810

811 Chen G (2004) Electrochemical technologies in wastewater treatment. Sep Purif Technol 38 (1): 11-41.

812 https://doi.org/10.1016/i.seppur.2003.10.006

813

814 Choi YY, Baek SR, Kim JI, Choi JW, Hur J, Lee TU, Park CJ, Lee BJ (2017) Characteristics and

815 Biodegradability of Wastewater Organic Matter in Municipal Wastewater Treatment Plants Collecting

816 Domestic Wastewater and Industrial Discharge, Water 9 (6): 1-12. https://doi.org/10.3390/w9060409 
818 Chopra AK, Sharma AK (2015) Effect of electrochemical treatment on the COD removal from biologically

819 treated municipal wastewater. Desalin Water Treat 53 (1): 41-47.

$820 \quad$ https://doi.org/10.1080/19443994.2013.836992

821

822 Deghles A, Kurt U (2015) Treatment of raw tannery wastewater by electrocoagulation technique:

823 optimization of effective parameters using Taguchi method. Desalin Water Treat 57 (32): 14798-14809.

824 https://doi.org/10.1080/19443994.2015.1074622

825

826 Demirci Y, Pekel LC, Alpbaz M (2015) Investigation of Different Electrode Connections in

827 Electrocoagulation of Textile Wastewater Treatment. Int J Electrochem Sci 10 (3): 2685-2693.

828

829 Diya'uddeen BH, Daud WMAW, Abdul Aziz AR (2011) Treatment technologies for petroleum refinery

830 effluents: A review. Process Saf Environ Prot 89 (2): 95-105. https://doi.org/10.1016/j.psep.2010.11.003

831

832 Diya'uddeen BH, Rahim Pouran Shima, Abdul Aziz AR, Daud, WMAW (2015) Fenton oxidative treatment 833 of petroleum refinery wastewater: process optimization and sludge characterization. RSC Adv 5 (83):

834 68159-68168. http://dx.doi.org/10.1039/C5RA08079G

835

836

Drogui P, Asselin M, Brar SK, Benmoussa H, Blais JF (2009) Electrochemical removal of organics and oil

837 from sawmill and ship effluents. Can J Chem Eng 36 (3): 529-539. https://doi.org/10.1139/L09-003

838

839 Eames D, O’Dell L, Aylesworth J (2017) Silica Precipitation Chemistry, What works and how much does it 840 cost? Industrial Wastewater Treatment Technology Database (IWTT) | US EPA. 841 https://watersgeo.epa.gov/iwtt/article-report-308. Accessed 15 March 2021. 
843 El-Ashtoukhy ESZ, El-Taweel YA, Abdelwahab O, Nassef EM (2013) Treatment of Petrochemical 844 Wastewater Containing Phenolic Compounds by Electrocoagulation Using a Fixed Bed Electrochemical 845 Reactor. Int J Electrochem Sci 8 (1): 1534 - 1550.

846

847 Elazzouzi M, Haboubi Kh, Elyoubi MS (2017) Electrocoagulation-flocculation as a low-cost process for 848 pollutants removal from urban wastewater. Chem Eng Res Des 117: 614-626. 849 https://doi.org/10.1016/i.cherd.2016.11.011

850

851 El-Dein AM, Libra J, Wiesmann U (2006) Cost analysis for the degradation of highly concentrated textile 852 dye wastewater with chemical oxidation H2O2/UV and biological treatment. J Chem Technol Biotechnol 85381 (1):1239-1245. https://doi.org/10.1002/jctb.1531

854

855 Fayad N (2017) The application of electrocoagulation process for wastewater treatment and for the 856 separation and purification of biological media. Chemical and Process Engineering. Université Clermont 857 Auvergne. https://tel.archives-ouvertes.fr/tel-01719756/document. Accessed 20 August 2020.

859 Gaied F, Louhichi B, Bali M, Jeday MR (2019) Tertiary treatment of wastewater by electro-coagulation, 860 electro-Fenton and advanced electro-oxidation processes: Comparative and economic study. 861 Songklanakarin J Sci Technol 41 (5): 1084-1092.

862

863 García-Morales MA, González Juárez JC, Martínez-Gallegos S, Roa-Morales G, Peralta E, del Campo López 864 EM, Barrera-Díaz C, Martínez Miranda V, and Blancas TT (2018). Pretreatment of Real Wastewater from 
865 the Chocolate Manufacturing Industry through an Integrated Process of Electrocoagulation and Sand

866 Filtration. Int J Photoenergy 2018: 1-7. https://doi.org/10.1155/2018/2146751

867

868 Gasim HA, Kutty SRM, Isa MH, Isa MPM (2012) Treatment of Petroleum Refinery Wastewater by using

869 UASB Reactors. International Scholarly and Scientific Research \& Innovation 6(2): 58-61.

870

871 GENESIS WATER TECHNOLOGIES Using Innovation to Meet the Water Needs of the World. Top 5

872 Advantages of Advanced Electrocoagulation Water Treatment (2019).

873 https://genesiswatertech.com/blog-post/top-5-advantages-of-advanced-electrocoagulation-water-

874 treatment/. Accessed 18 February 2020.

875 GilPavas E, Molina-Tirado K, Gómez-García MÁ (2009) Treatment of automotive industry oily 876 wastewater by electrocoagulation: statistical optimization of the operational parameters. Water Sci

877 Technol 60 (10): 2581-2588. https://doi.org/10.2166/wst.2009.519

878 Giorgi J (2009) Math for wastewater treatment operators grades 3 and 4. First edition. American Water 879 Works Association.

880 Giwa SO, Giwa A, Zeybek Z, Hapoglu H (2013) Electrocoagulation Treatment of Petroleum Refinery 881 Wastewater: Optimization through RSM. Int J Eng Res Technol 2 (8): 606-615.

882

883 Gomes J, Cocke D, Das K, Guttula M, Tran D, Beckman J (2009) Treatment of produced water by 884 electrocoagulation.

885 https://www.avividwater.com/uploads/1/3/1/6/131696832/gomes 2009 treatment of produced wat 886 er by electrocoagulation.pdf. Accessed 25 October 2021. 
888 Gousmi N, Sahmi A, Li HZ, Poncin S, Djebbar R, Bensadok K (2016) Purification and detoxification of

889 petroleum refinery wastewater by electrochemical process. Environ Technol 37 (18): 2348-2357.

$890 \quad$ http://dx.doi.org/10.1080/09593330.2016.1150349

891 Guvenc SY, Erkan HS, Varank G, Bilgili MS, Engin GO (2017) Optimization of paper mill industry

892 wastewater treatment by electrocoagulation and electro-Fenton processes using response surface

893 methodology. Water Sci Technol 76 (8): 2015-2031. https://doi.org/10.2166/wst.2017.327

894

895 Hu G, Li J, Zeng G (2013) Recent development in the treatment of oily sludge from petroleum industry: A

896 review. J Hazard Mater 261: 470-490. https://doi.org/10.1016/i.jhazmat.2013.07.069

897

898 Jafarinejad S (2017) Cost estimation and economical evaluation of three configurations of activated

899 sludge process for a wastewater treatment plant (WWTP) using simulation. Appl Water Sci 7 (5): $2513-$

900 2521. https://doi.org/10.1007/s13201-016-0446-8

901

902 Jeuland M (2015) Challenges to wastewater reuse in the Middle East and North Africa. Middle East Dev J

9037 (1): 1-25. http://dx.doi.org/10.1080/17938120.2015.1019293

904

905 Jimenez JA, La Motta EJ, and Parker DS (2005) Kinetics of Removal of Particulate Chemical Oxygen

906 Demand in the Activated-Sludge Process. Water Environ Res 77 (5): 437-446.

$907 \quad$ https://doi.org/10.2175/106143005X67340.

908

909 Johnson OA, Affam AC (2019) Petroleum sludge treatment and disposal: A review. Environ Eng Res 24

910 (2): 191-201. https://doi.org/10.4491/eer.2018.134

911 
912 Jordan Refinery Company annual report $\quad$ (2018).

913 http://www.jopetrol.com.jo/EchoBusV3.0/SystemAssets/33b159f2-5de7-4113-a8b1-372baee2a7cf.pdf.

914 Accessed 25 August 2020.

915

916 Keramati M, Ayati B (2019) Petroleum wastewater treatment using a combination of electrocoagulation

917 and photocatalytic process with immobilized ZnO nanoparticles on concrete surface. Process Saf Environ

918 Prot 126: 356-365. https://doi.org/10.1016/j.psep.2019.04.019

919

920 Kobya M, Delipinar S (2008) Treatment of the baker's yeast wastewater by electrocoagulation, J Hazard

921 Mater 154 (1-3): 1133-1140. https://doi.org/10.1016/j.jhazmat.2007.11.019

922

923 Kobya M, Demirbas E, Akyol A (2009) Electrochemical treatment and operating cost analysis of textile 924 wastewater using sacrificial iron electrodes. Water Sci Technol 60 (9): 2261-2270.

925 https://doi.org/10.2166/wst.2009.672

926

927 Kobya M, Ozyonar F, Demirbas E, Sik E, Oncel MS (2015) Arsenic removal from groundwater of Sivas-

928 Şarkişla Plain, Turkey by electrocoagulation process: Comparing with iron plate and ball electrodes. J

929 Environ Chem Eng 3 (2): 1096-1106. https://doi.org/10.1016/j.jece.2015.04.014

930

931 Kongjao S, Damronglerd S, Hunsom M (2008) Simultaneous removal of organic and inorganic pollutants

932 in tannery wastewater using electrocoagulation technique. Korean J Chem Eng 25 (4): 703-709.

933 https://doi.org/10.1007/s11814-008-0115-1 
935 Kulikowska D, Zielińska M, Konopka K (2019) Treatment of stabilized landfill leachate in an integrated

936 adsorption-fine-ultrafiltration system, Int J Environ Sci Technol 16 (1): 423-430.

937 https://doi.org/10.1007/s13762-018-1685-z

938

939 Li A (2013) Biological Wastewater Treatment: Selecting the Process. Veolia Water Solutions \& 940 Technologies. $\quad$ https://www.chemengonline.com/biological-wastewater-treatment-selecting-the-

941 process/. Accessed 13 August 2020.

942

943 Lin CJ, Lo SL, Kuo CY, Wu CH (2005) Pilot-Scale Electrocoagulation with Bipolar Aluminum Electrodes for 944 On-Site Domestic Greywater Reuse. J Environ Eng 131 (3): 491-495.

945 https://doi.org/10.1061/(ASCE)0733-9372(2005)131:3(491)

946

947 Liu F, Zhang Z, Wang Z, Li X, Dai X, Wang L, Wang X, Yuan Z, Zhang J, Chen M, Wang S (2019)

948 Experimental study on treatment of tertiary oil recovery wastewater by electrocoagulation. Chem Eng

949 Process 144: 107640. https://doi.org/10.1016/j.cep.2019.107640

950

951 Mahesh S, Garg KK, Srivastava VC, Mishra IM, Prasad B, Mall ID (2016) Continuous electrocoagulation

952 treatment of pulp and paper mill wastewater: operating cost and sludge study. RSC Adv 6 (20): 16223-

953 16233. https://doi.org/10.1039/C5RA27486A

954

955 Marin JA, Hernandez T, Garcia C (2005) Bioremediation of oil refinery sludge by landfarming in semiarid 956 conditions: Influence on soil microbial activity. Environ Res 98 (2): 185-195.

957 https://doi.org/10.1016/i.envres.2004.06.005 
959 Martin L (2014) Electrocoagulation: A Shocking Approach To Wastewater Treatment.

960 https://www.wateronline.com/doc/a-shocking-approach-to-wastewater-treatment-0001. Accessed 18

961 February 2020.

962

963 McFarland M (2000) Biosolids Engineering. McGraw-Hill Professional.

964

965 Mohammadi MJ, Salari J, Takdastan A, Farhadi M, Javanmardi P, Yari AR, Dobaradaran S, Almasi H,

966 Rahimi S (2017) Removal of turbidity and organic matter from car wash wastewater by 967 electrocoagulation process. Desalination Water Treat 68: 122-128.

968 https://doi.org/10.5004/dwt.2017.20319

969

970 Mohlman, FM (1934) The Sludge Index. Sewage Work J 6: 119-122.

971 Mohsen MS, Jaber JO (2002) Potential of industrial wastewater reuse. Desalination 152(1-3):281-289.

$972 \quad$ https://doi.org/10.1016/S0011-9164(02)01075-5

973

974 Neutrium (2012). https://neutrium.net/equipment/pump-power-calculation/. Accessed 12 March 2020.

975

976 Ozyonar F (2016) Treatment of Train Industry Oily Wastewater by Electrocoagulation with Hybrid 977 Electrode Pairs and Different Electrode Connection Modes. Int J Electrochem Sci 11 (2): 1456 - 1471.

978

979

980 Panizza M (2018) Fine Chemical Industry, Pulp and Paper Industry, Petrochemical Industry and

981 Pharmaceutical Industry. In: Martínez-Huitle CA, Rodrigo MA, Scialdone O (eds) Electrochemical Water 982 and Wastewater Treatment. Elsevier, Oxford-Massachusetts, pp 335-364. 
983 Pérez LS, Rodriguez OM, Reyna S, Sánchez-Salas JL, Lozada JD, Quiroz MA, Bandala ER (2015) Oil refinery

984 wastewater treatment using coupled electrocoagulation and fixed film biological processes. Phys Chem

985 Earth, Parts A/B/C 91: 53-60. https://doi.org/10.1016/i.pce.2015.10.018

986

987 Peters MS, Timmerhaus KD (1991) Plant Design and Economics for Chemical Engineers, fourth ed. 988 McGraw-Hill.

989

990 Qadir M, Bahri A, Sato T, al-Karadsheh E, (2010). Wastewater production, treatment and irrigation in 991 Middle East and North Africa. Irrig Drainage Syst 24 (1-2): 37-51. https://doi.org/10.1007/s10795-009-

$992 \underline{9081-y}$

993

994

995 Records A, Sutherland K (2001) Decanter Centrifuge Handbook, $1^{\text {st }}$ edn. Elsevier, UK.

996

997 Saber A, Hasheminejad H, Taebi A, Ghaffari G (2014) Optimization of Fenton-based treatment of 998 petroleum refinery wastewater with scrap iron using response surface methodology. Appl Water Sci 4

999 (3): 283-290. https://doi.org/10.1007/s13201-013-0144-8

1000

1001 Sahu OP, Gupta V, Chaudhari PK, Srivastava VC (2015) Electrochemical treatment of actual sugar 1002 industry wastewater using aluminum electrode, Int J Environ Sci Technol 12 (11): 3519-3530. 1003 https://doi.org/10.1007/s13762-015-0774-5

1004 
1005 Said HK, Mostefa NM (2015) Optimization of Turbidity and COD Removal from Pharmaceutical 1006 Wastewater by Electrocoagulation. Isotherm Modeling and Cost Analysis. Pol J Environ Stud 24 (3):

1007 1049-1061. https://doi.org/10.15244/pjoes/32334

1008

1009 Sakhel SR, Geissen SU, Vogelpohl A (2017) Virtual industrial water usage and wastewater generation in 1010 the Middle East and North Africa 2011-2015. Euro-Mediterr J Environ Integr 2 (1): 1-18.

1011 https://doi.org/10.1007/s41207-017-0018-9

1012

1013 Sardari K (2018) Membrane-based Separation Processes for Treating High Salinity Produced Waters. PhD

1014 Thesis, Une University of Aransas,

1015 https://scholarworks.uark.edu/cgi/viewcontent.cgi?article=4394\&context=etd, accessed 25 October 10162021.

1017

1018 Sharma, J R (2010) Development of a preliminary cost estimation method for water treatment plants.

1019 MSc thesis, The University of Texas, Arlington. https://rc.library.uta.edu/uta1020 ir/bitstream/handle/10106/4924/Sharma uta 2502M 10652.pdf?sequence $=1 . \quad$ Accessed $3^{\text {rd }}$ of

$1021 \quad$ November 2019.

1022 Soares RB, Memelli MS, Roque RP, Gonçalves RF (2017) Comparative Analysis of the Energy 1023 Consumption of Different Wastewater Treatment Plants. International Journal of Architecture, Arts and 1024 Applications 3 (6): 79-86. https://doi.org/10.11648/i.ijaaa.20170306.11

1025 Sprick M (2017) Comparison of Options for Biosolids Dewatering. Water Environment School, Clackamas 1026 Community College. https://www.clackamas.edu/docs/default-source/degrees-

1027 certificates/departments-programs/wet-orwef---biosolids-comparison-of-biosolids-dewatering1028 options-(current).pdf?sfvrsn=5ba8d68 0, accessed 8 April 2021. 
1030 Sridhar R, Sivakumar V, Maran JP, Thirugnanasambandham K (2014) Influence of operating parameters 1031 on treatment of egg processing effluent by electrocoagulation process, Int J Environ Sci Technol 11 (6):

1032 1619-1630. https://doi.org/10.1007/s13762-013-0301-5

1033

1034 Srinivas T (2008) Environmental Biotechnology. New Age International (P) Limited, Publishers. New 1035 Delhi.

1036

1037 Srivastav M; Gupta M; Agrahari SK; Detwal P (2019) Removal of Refractory Organic Compounds from 1038 Wastewater by Various Advanced Oxidation Process - A Review, Curr Environ Eng 6(1): 8-16. 1039 https://doi.org/10.2174/2212717806666181212125216

1040

1041 Tanyol M, Ogedey A, Oguz E (2018) COD removal from leachate by electrocoagulation process: 1042 treatment with monopolar electrodes in parallel connection. Water Sci Technol 77 (1): 177-186. $1043 \quad$ https://doi.org/10.2166/wst.2017.528

1044

1045 Tetreault A (2003) Electrocoagulation Process for Wastewater Treatment. EC Pacific Pty Ltd. 1046 https://www.ampc.com.au/uploads/cgblog/id172/ENV 2003 Electrocoagulation process for wastewa 1047 ter treatment.pdf. Accessed 15 March 2021.

1048

1049 The Hashemite Kingdom of Jordan Environment Statistics 2014-2015 (2018).

1050 https://unstats.un.org/unsd/environment/Compendia/Jordan Environment\%20Statistics,\%202014-

$1051 \quad$ 2015.pdf. Accessed 28 March 2021.

1052 
1053 Theobald D (2014) Math Solutions: Pump Performance And Efficiency Calculations. 1054 https://www.wateronline.com/doc/math-solutions-pump-performance-and-efficiency-calculations-

1055 0001. Accessed 5 June 2020.

1056

1057 United States Environmental Protection Agency (US EPA) (1985) Estimating Sludge Management Costs, 1058 Water Engineering Research Laboratory. EPA/625/6-85/010.

1059

1060 US EPA (2012) Hazardous Waste Listings. A User-Friendly Reference Document. 1061 https://www.epa.gov/sites/production/files/2016-01/documents/hw listref sep2012.pdf, accessed 26 1062 February 2021.

1063 US EPA (1995) How to Evaluate Alternative Cleanup Technologies for Underground Storage Tank Sites. A 1064 Guide for Correction Action Plan Reviewers. EPA 510-B-95-007.

1065 Varank G, Erkan H, Yazýcý S, Demir A, Engin G (2014) Electrocoagulation of Tannery Wastewater using 1066 Monopolar Electrodes: Process Optimization by Response Surface Methodology. Int J Environ Res 8 (1): $1067 \quad 165-180$.

1068

1069 Von Sperling M and Gonçalves RF (2007) Sludge characteristics and production. In: Andreoli CV, Von 1070 Sperling M, and Fernandes F (eds.) Sludge Treatment and Disposal. IWA Publishing, London-New York, 1071 pp. 4-30.

1072

1073 Wake H (2005) Oil refineries: a review of their ecological impacts on the aquatic environment. Estuar 1074 Coast Shelf Sci 62 (1-2): 131-140. https://doi.org/10.1016/j.ecss.2004.08.013

1075 
1076 Wang S, Xu W, Cheng Z (2011) Method of removing recalcitrant organic pollutant, European Patent 1077 Office (EP2683660A1). https://patents.google.com/patent/EP2683660A1/en

1078

1079 Yuksel E, Gurbulak E, Eyvaz M (2012) Decolorization of a Reactive Dye Solution and Treatment of a 1080 Textile Wastewater by Electrocoagulation and Chemical Coagulation: Techno-Economic Comparison. 1081 Environ Prog Sustain 31 (4): 524-535. https://doi.org/10.1002/ep.10574

1082

1083 Zazouli MA, Taghavi M, Bazrafshan E (2012) Influences of Solution Chemistry on Phenol Removal From 1084 Aqueous Environments by Electrocoagulation Process Using Aluminum Electrodes. J Health Scope 1 (2):

1085 66-70. https://dx.doi.org/10. 5812/jhs.5462 


\section{Supplementary Files}

This is a list of supplementary files associated with this preprint. Click to download.

- SupplementarymaterialENPR1.docx 